\title{
Capitalism's Alter Ego: The Birth of Reciprocity in Eighteenth-Century France
}

Charles Walton, University of Warwick

\begin{abstract}
This article traces the concept of reciprocity from its emergence in French philosophy during the Enlightenment to its recent growth in the humanities and social sciences. After charting the term's accelerated use in French and English in the modern period, the article shows how its meaning has continually wavered between exchange equivalence (barter) and generosity and obligation (the gift, the Golden Rule). During the Enlightenment, these meanings converged in efforts to naturalize commerce and justify liberal economic reforms. A free-market society, it was argued, would be fair and bountiful. Upon the failure of such reforms in the early French Revolution, reciprocity and its new synonym "fraternity" became detached from economic liberalism. As capitalism became increasingly associated with wealth inequality in the nineteenth century, reciprocity became the watchword of capitalism's critics, who tried to conceptualize social bonds in terms other than those offered by Homo economicus.
\end{abstract}

In reciprocity, profit cannot exist.

-Pierre Larousse, Dictionnaire universel du XIXe siècle

$n$ recent decades, the concept of reciprocity has spread across the humanities and social sciences. It appears these days in a wide range of disciplines, from philosophy, politics, and economics to communications, religion, and behavioral

I would like to thank the editors and anonymous readers of Critical Historical Studies for their helpful comments on an earlier draft of this article. I am especially grateful to Natalie Zemon Davis, who inspired my interest in reciprocity; to William Sewell, who shared his own related research with me; and to Daniel Lord Smail, who alerted me to recent critiques of reciprocity in anthropology. Thanks go also to colleagues who have provided valuable input on this project: Julia Abramson, Keith Baker, David Bell, Paul Cohen, Brian Cowan, Nicolas Delalande, William Doyle, David Garrioch, Mark Goodale, Lisa Jane Graham, Olivier Grenouilleau, Lynn Hunt, Colin Jones, Minchul Kim, Antointe Lilti, Jean-Clément Martin, Peter McPhee,

Critical Historical Studies (Spring 2018). () 2018 by The University of Chicago. All rights reserved. 2326-4462/2018/0501-0001\$10.00 
science. ${ }^{1}$ Its rise in academic research is borne out by online catalogs and text collections. JSTOR's collection of more than 2,300 journals, for example, shows a dramatic increase in the term's use since the 1980s (fig. Al). It also shows a broadening of usage: before the 1970s, "reciprocity" referred mostly to international trade. Since then, its sociological and philosophical meanings have predominated, even in articles on business and economics (fig. A2). ${ }^{2}$

This is not the first time in history that invocations of reciprocity have suddenly surged. Something similar occurred with the French réciprocité in the latter half of the eighteenth century. Before 1750, the term appeared rarely-mostly in discussions of commercial treaties and marriage contracts. ${ }^{3}$ After 1750, it burst into tracts on civil society, political economy, rights and duties, and the social contract. It acquired philosophical freight, referring to how individuals related to one another in society-or how they should relate to one another.

Reciprocity is thus a modern concept. It emerged during the Enlightenment, precociously in France, and has been invoked increasingly ever since. Curiously, though, historians have tended to associate it with the pre- and early modern. Borrowing from the cultural anthropology of archaic societies, medieval and early modern European historians have employed reciprocity and the related concept of gift giving to interpret a wide range of social practices, from clientelism and char-

Eve Morisi, Samuel Moyn, Mark Philp, Jeffrey Ravel, Giorgio Riello, Stephen Sawyer, Pierre Serna, Jennifer Sessions, J. B. Shank, David K. Smith, Céline Spector, and Francesca Trivellato. I am grateful to Geno Chou and Nastia van Der Meer for their assistance in preparing the manuscript and to colleagues and staff at the Paris Institute for Advanced Studies, where research on this project was largely completed in 2016.

1. For recent examples in each of these disciplines, see, for philosophy, Kazutaka Inamura, Justice and Reciprocity in Aristotle's Political Philosophy (Cambridge: Cambridge University Press, 2015); for politics, Frederico Finan and Laura Schechter, "Vote-Buying and Reciprocity" (working paper, January 2010), http://www.parisschoolofeconomics.eu/docs/ydepot/semin/texte0910/FIN2010VOT.pdf; for economics, Serge-Christophe Kolm and Jean Mercier Ythier, eds., The Handbook of the Economics of Giving, Altruism and Reciprocity, 2 vols. (Amsterdam: Elsevier, 2006); for communication studies, Avery E. Holton, Mark Coddington, Seth C. Lewis, and Homero Gil de Zúñiga, "Reciprocity and the News: The Role of Personal and Social Media Reciprocity in News Creation and Consumption," International Journal of Communication 9 (2015): 2526-47; for religious studies, Douglas J. Davies, Emotion, Identity, and Religion: Hope, Reciprocity, and Otherness (Oxford: Oxford University Press, 2011); and for behavioral science, Samuel Bowles and Herbert Gintis, A Cooperative Species: Human Reciprocity and Its Evolution (Princeton, NJ: Princeton University Press, 2011).

2. JSTOR titles with "reciprocity" in business and economics between 1980 and 2015 show a shift toward sociological uses of the term. See, for example, Sebastien Kube, Michel André Maréchal, and Clemens Puppe, "The Currency of Reciprocity: Gift-Exchange in the Workplace," American Economic Review 102, no. 4 (June 2012): 1644-62.

3. Examples of its use in pre-Enlightenment commercial treaties will be discussed below. For its use in the jurisprudence on marriage contracts, see Philippe de Renusson, Traitez du douaire et de la garde-noble et bourgeoise, qu'on appelle bail en plusieurs coustumes (Paris: La Comapgnie des libraires, 1724), 110; Antoine Gaspard Boucher d'Argis, Principes sur la nullité du mariage, pour cause d'impuissance (London [Paris]: n.p., 1756). 
ity to religious conversions and early global commerce. ${ }^{4}$ Enlightenment scholars, for their part, have found the concept of reciprocity (not the practice) in certain strands of eighteenth-century thought, especially the writings of Jean-Jacques Rousseau. But they tend to refer to the concept in a general way and do not historicize the term carefully, examining its precise uses and meanings. ${ }^{5}$ (Rousseau, in fact, never invoked reciprocity, despite its growing currency at the time.) Moreover, their analyses do not extend much beyond 1789. Meanwhile, modern historians have next to nothing to say about reciprocity. Neither the concept nor the practice figures in analyses of post-Enlightenment European societies.

Given the current state of the historiography, then, it would appear that reciprocity died in the age of Rousseau, a time when early modern gift-giving culture presumably gave way to modern capitalism. ${ }^{6}$ Such a conclusion, however, runs

4. Seminal studies of reciprocity and gift giving include Richard Thurnwald, Bánaro Society: Social Organization and Kinship System of a Tribe in the Interior of New Guinea (Lancaster, PA: New Era, 1916); Bronislaw Malinowski, Argonauts of the Western Pacific: An Account of Native Enterprise and Adventure in the Archipelagoes of Melanesian New Guinea (London: Routledge, 1922); and Marcel Mauss, The Gift: Form and Reason for Exchange in Archaic Societies, trans. W. D. Halls (New York: Norton, 1990). For historical studies of medieval and early modern Europe that employ "gift giving" and "reciprocity," see Sharon Kettering, "Brokerage at the Court of Louis XIV," The Historical Journal 36, no. 1 (March 1993): 69-87, and "Patronage in Early Modern France," French Historical Studies 17, no. 4 (Autumn 1992): 839-62; Laurence Fontaine, L'économie morale: Pauvreté, crédit et confiance dans l'Europe préindustrielle (Paris: Gallimard, 2008); and Natalie Zemon Davis, The Gift in Sixteenth-Century France (Madison: University of Wisconsin Press, 2000). For the use of reciprocity and gift giving to interpret Viking conversions to Christianity, see Anders Winroth, The Conversion of Scandinavia: Vikings, Merchants, and Missionaries in the Remaking of Northern Europe (New Haven, CT: Yale University Press, 2012). For gifts and reciprocity in the rise of commerce, see Martha Howell, Commerce before Capitalism in Europe, 1300-1600 (Cambridge: Cambridge University Press, 2010) and Anne Goldgar, Tulipmania: Money, Honor, and Knowledge (Chicago: University of Chicago Press, 2007).

5. Jonathan Israel observes that radical Enlightenment philosophers sought to construct a new moral order "exclusively on the principles of equity and reciprocity," but that is that last occurrence of "reciprocity" for the remaining thousand pages of the book Democratic Enlightenment (Oxford: Oxford University Press, 2011), 23. Paul de Man writes, "Reciprocity . . f for Rousseau is the very condition of love" in Allegories of Reading: Figural Language in Rousseau, Nietzsche, Rilke, and Proust (New Haven, CT: Yale University Press, 1979), 283. Additional studies associating Rousseau with the principle include Judith Still, Justice and Difference in the Works of Rousseau: Bienfaisance and Pudeur (Cambridge: Cambridge University Press, 1993), 9, 68-81; Jean Starobinski, "Introduction," in Jean-Jacques Rousseau, Discours sur l'origine et les fondements de l'inégalité parmi les hommes (Paris: Gallimard, 1996), 15.

6. Associating reciprocity with precapitalist societies is often attributed to Karl Polanyi, The Great Transformation: The Political and Economic Origins of Our Times (1944; Boston: Beacon, 1957). For a critique of this premodern-modern dichotomy, see Clare Haru Crowston, "Credit and the Metanarrative of Modernity," French Historical Studies 34, no. 1 (2011): 7-19. In The Return of the Gift: European History of a Global Idea (Cambridge: Cambridge University Press, 2011), Harry A. Liebersohn argues that the late eighteenth century saw a delegitimization of gift-giving practices, which looked corrupt from new normative perspectives privileging commerce and rational administration. Reciprocity and gift giving would reemerge, he shows, in the twentieth century but as concepts for understanding archaic rather than modern societies. In her study of French Revolutionary novels, Geneviève Lafrance identifies growing pessimism about the prospects of reciprocity to create social happiness during the French Revolution in Qui perd gagne: Imaginaire du don et Révolution française (Montreal: University of Montreal, 2008). 
counter to the evidence. Rather than declining with the rise of capitalism, the concept appears to have emerged along with it. Invocations of reciprocity increased as capitalism expanded-surging, as well shall see, in periods of contentious economic change.

Despite reciprocity's importance across the modern era, little is known about the concept's history. The most developed account comes not from a historian but from a cultural anthropologist. In Inalienable Possessions: The Paradox of Keeping-WhileGiving (1992), Annette B. Weiner traces the concept back to the medieval period, when a "norm of reciprocity" began shaping descriptions of political society. (The term, we will see, was rarely invoked before the Enlightenment.) In the seventeenth and eighteenth centuries, she continues, the principle came to justify economic liberalism: "Beginning with Thomas Hobbes, the notion in political philosophy of a norm of reciprocity as a fundamental principle in human society entered into speculations to justify the rise of a free-market economy without state interventions." ${ }^{7}$ Seeking a moral basis for commercial capitalism, Enlightenment philosophers asserted that "when people enter into reciprocal exchange [i.e., the market], they become better people." ${ }^{8}$ After the Enlightenment, Weiner argues, the concept went from justifying free-market capitalism to providing a frame of reference for critiquing it. Thus, when anthropologists in the early twentieth century began characterizing the exchange practices of archaic societies in terms of reciprocity, they sought in these practices alternatives to, or the purer origins of, capitalism- "purer" for being less hierarchical, less utilitarian, and less alienating: "The economic world of the 'primitive' was viewed as both the antithesis and alter ego of Western Homo aconomicus." 9

Packing six centuries of history into a few pages, Weiner's sketch may not convince historians. (Can Hobbes and Adam Smith really be lumped together as pioneers of economic liberalism?) But it serves her main purpose of exposing how anthropologists have unwittingly projected liberal economic notions inherited from the Enlightenment onto archaic societies, making those societies' exchange practices

7. Annette B. Weiner, Inalienable Possessions: The Paradox of Keeping-While-Giving (Berkeley: University of California Press, 1992), 28.

8. Ibid. Historians have developed this point. See Albert Hirschman, The Passions and the Interests: Political Arguments for Capitalism before Its Triumph (Princeton, NJ: Princeton University Press, 1977). For the links between morality and political economy during the Enlightenment, see Emma Rothschild, Economic Sentiments: Adam Smith, Condorcet, and the Enlightenment (Cambridge, MA: Harvard University Press, 2001); John Shovlin, The Political Economy of Virtue: Luxury, Patriotism, and the Origins of the French Revolution (Ithaca, NY: Cornell University Press, 2006); and Michael Sonenscher, Before the Deluge: Public Debt, Inequality, and the Intellectual Origins of the French Revolution (Princeton, NJ: Princeton University Press, 2007).

9. Weiner, Inalienable Possessions, 30. She adds, "These projected images of reciprocity as the basis for an equitable economics in which Western society had originally participated were widely agreed upon." 
appear more balanced than they really were. Reciprocity obscures hierarchies, she insists, not only in archaic societies but also in modern ones-a point well worth considering, given the concept's growing prominence in the social sciences these days. ${ }^{10}$ More relevant for this article, however, is her hypothesis of a historical shift from reciprocity as a justification for free-market capitalism during the Enlightenment to reciprocity as capitalism's antithesis and alter ego in later periods. She identifies this change but does not explain it. In what follows, I argue that it began in the age of the French Revolution-a time when faith in economic liberalism's promise of social peace and mutual benefits began to flag. Although reciprocity may have been useful for delegitimizing privilege and patronage before 1789, once the Old Regime collapsed, the concept failed to legitimize economic liberalism and, eventually, was used to critique it.

Before beginning this account, it may be helpful to explain why I, a historian of political culture, have decided to venture into conceptual history. A few years ago, I set out to write a narrative of the French Revolution from the perspective of reciprocity and redistribution. Drawing on cultural anthropology, I aimed to demodernize the revolution by showing how these conceptual tools, usually reserved for studying premodern societies, could be used to study modern ones as well. After all, if social scientists in other disciplines were putting them to good use to analyze the present and recent past, why were historians limiting their use of them to the pre- and early modern? As it turns out, redistribution has been helpful for interpreting French Revolutionary politics. ${ }^{11}$ Reciprocity, however, has not. It crumbled like sand as soon as I tried to use it to drill into the past. What is reciprocity to begin with? Does it refer to equivalent exchanges (barter) or to generosity and obligation (gift giving)? Do exchanges have to be balanced to be reciprocal, or does any exchange qualify, even if it instantiates hierarchy or indebtedness? And is reciprocity ultimately a matter of economic exchange or of the honor, dignity, and mutual recognition of the exchangers? The more I delved into the theoretical literature on reciprocity, the more unwieldy the concept became. It referred to too many different things.

My doubts crystallized upon reading David Graeber's Debt: The First Five Thousand Years (2013). Skeptical about the concept, the anthropologist observes, "If

10. Ibid., 150-55.

11. I am currently completing a narrative of the French Revolution from the perspective of redistributive politics. For my early efforts to interpret revolutions through the lens of redistribution, see my "Révolution et redistribution: Réflexions sur la France et l'Égypte," La Vie des idées (April 23, 2013), http://www .laviedesidees.fr/Revolution-et-redistribution.html, and in English as "Revolution and Redistribution: Reflections on France and Egypt," Books and Ideas.net (2013), http://www.booksandideas.net/Revolution -and-Redistribution.html. 
one has decided that all relations are based on reciprocity, one can always define the term so broadly as to make it true." ${ }^{12}$ That was my problem. In stretching reciprocity to encompass a wide range of social relations before, during, and after the French Revolution, it lost all explanatory power. It certainly could not explain historical change. I gradually came to share Graeber's and Weiner's misgivings about the concept: in implying equity and balance (a legacy of Enlightenment theories of commercial society), reciprocity imbues social relations with an undue degree of egalitarian normativity, obscuring hierarchy and debt. Indeed, the concept's propensity to obscure structural imbalances is precisely why economic liberals during the Enlightenment found it so useful. It helped them in their campaign against privilege by allowing them to foreground civil equality while throwing wealth inequality and indebtedness into the background. The two anthropologists reject reciprocity on these very grounds and propose conceptual alternatives- "debt" (Graeber) and "inalienable possessions" (Weiner)—concepts that better account for systemic power asymmetries. ${ }^{13}$

While grappling with these methodological challenges, I stumbled upon Google Books Ngram Viewer and discovered that the term "réciprocité" gained currency in the very period I was studying. In examining its early uses, I discerned meanings and tensions that resonated with the ones I had encountered in the theoretical literature on gift giving and reciprocity. It struck me that we are still entangled in philosophical knots formed more than two centuries ago. By unpicking those knots-by historicizing reciprocity's meanings, uses, and political implications-I aimed to discover patterns in how social relations have been understood since the Enlightenment. At the very least, I hoped to understand how the concept figured in the French Revolution. Did notions of reciprocity shape revolutionary ideals? Did the revolution reshape notions of reciprocity? With these questions, I abandoned the search for reciprocal social practices and set out to historicize the concept.

What follows is a history of reciprocity in the eighteenth century, when the term first gained currency as a philosophical concept. I begin by charting its rise in French texts and comparing its use frequency with the English "reciprocity" and other key Enlightenment and Revolutionary terms, such as "liberty," “equality,"

12. David Graeber, Debt: The First Five Thousand Years (2011; repr., New York: Melville House, 2014), 413 n. 21 . Graeber critiques reciprocity (89-126) for its ties to classical economic theories of barter. In my view, his effort to replace the concept of reciprocity with that of debt amounts to privileging one side of a conceptual dichotomy running through reciprocity since the eighteenth century-the obligation side over the exchange-equivalence side. His great contribution to exchange theory, I believe, is to have identified the political violence inherent in quantifying obligations as debts that must be repaid.

13. Ibid., 89-126. For an elaboration of Weiner's concept of "inalienable possessions," see Maurice Godelier, The Engima of the Gift, trans. Nora Scott (Cambridge: Polity, 1999). 
and "fraternity." I then discuss the concept's intellectual and social origins. I locate its intellectual origins in a shift from subjugation to moral equality as the philosophical basis of societal obligations. The term's dramatic rise in French texts after 1750, however, owed to social factors, specifically, the rise of commercial and financial capitalism. In radically altering social relations, capitalism sparked philosophical reflection on the nature of social bonds. Next, I examine the term's meanings. I identify a tension between reciprocity as the voluntary and utilitarian exchange of equivalents (barter) and reciprocity as exchange inspired by generosity and obligation (the gift, the Golden Rule). Economic liberals of the Enlightenment tried to fuse these meanings, but their compound proved to be unstable. It exploded in the French Revolution, when failed experiments with liberal economic policies fueled antipathy toward unshared wealth accumulation. Throughout the nineteenth and twentieth centuries (discussed briefly in the conclusion), reciprocity's meaning continued to waver between exchange equivalence and generosity and obligation-between barter and the Golden Rule. But it now stood opposed to profit seeking and free trade. It became, as Weiner observes, free-market capitalism's "antithesis and alter ego."

\section{THE RISE OF RÉCIPROCITÉ: TEXTUAL TRENDS}

Although the French adjective réciproque dates from the fourteenth century (a cognate of the Latin reciprocus), the substantive noun réciprocité appeared rarely in French texts before the Enlightenment. Nor did the noun exist in classical Latin; the closest term one can find is the clunky sic mutuo implicantur. Online text collections show that "réciprocité" did not gain currency until the mid-eighteenth century. ${ }^{14}$ Although data culled from online resources must be treated with caution-there are omissions and redundancies in the result sets-they all point to the same conclusion: "réciprocité" appeared more frequently in absolute and relative terms after 1750 (fig. A4 and A5). ${ }^{15}$ The English "reciprocity" lagged behind the French term by about

14. The online resources consulted for this study include Google Ngram Viewer, Gale's collections “The Making of the Modern World" and "Eighteenth Century Collections Online," and ARTFL-Frantext. "The Making of the Modern World" text collection shows only two tracts with "réciprocité" between 1600 and 1700 but 19 tracts between 1700 and 1750, most of which concern trade. The figure jumps dramatically to 347 tracts for the period between 1751 and 1800. Google Books also identifies only two publications containing the word "réciprocité" before 1700, albeit different ones than "The Making of the Modern World." For the fourteenth-century appearance of the adjective "réciproque," see Trésor de la langue française, Centre national de Ressources Textuelles et Lexicales, etymology for "réciproque," http://www.cnrtl.fr/etymologie/r\%C3\%A9ciproque.

15. For a study of the limitations of Google Ngram Viewer, see Eitan Adam Pechenick, Christopher M. Danforth, and Peter Sheridan Dodds, "Characterizing the Google Books Corpus: Strong Limits to Inferences of Socio-Cultural and Linguistic Evolution," PLoS One 10, no. 10 (2015): 1-24. 
20 years. ${ }^{16}$ True, the synonym "reciprocation" appeared earlier, but "reciprocity" overtook it in the 1780s (fig. A6). Overall, anglophone writers were less inclined to use either term-"reciprocation" or "reciprocity" - than the French were to use "réciprocité." 17 According to Google Ngram Viewer, the French invoked the concept 7 to 10 times more frequently than their anglophone counterparts in the latter half of the century. According to "The Making of the Modern World," the French appeared to have done so twice as often. These data suggest a greater interest in, or anxieties about, social bonds on the part of the French.

Lest Google Ngram frequencies seem too low to be significant (fig. A4), it is worth noting that although "réciprocité" has not appeared as often as "liberté" or "égalité" across the modern era, its frequency approximates that of the synonym "fraternité," except during the revolutions of 1789, 1848, and 1917 (World War I), when fraternité surpasses it (fig. A7). ${ }^{18}$

Other evidence corroborates reciprocity's rise in the latter half of the eighteenth century. The term appeared with different frequencies in two editions of François Véron Duverger de Forbonnais's Élements du commerce, published nearly a half century apart (1754 and 1796). A member of the Gournay circle, a group of political economists pioneering antimercantilist theories, Forbonnais took the innovative step of placing commerce-and reciprocity—at the heart of all social orders, "primitive" and "civilized." No longer limited to international relations, reciprocity became a core principle of civil society as well. ${ }^{19}$ But whereas Forbonnais himself used the term sparingly in the 1754 edition, the redactors of a new edition in 1796 multiplied its use. In the first edition, the noun "réciprocité" appears only

16. Although Google Ngram, which shows the proportionate usage of terms, indicates spikes in the early eighteenth century (fig. 4), these are statistically insignificant because it indicates the relative, not absolute, frequencies of terms among all terms appearing in the Google Books corpus. In absolute terms, the early eighteenth-century spike refers to only one title between 1710 and 1718 . The mid-eighteenthcentury spike between 1755 and 1766, however, consists of 97 titles.

17. For the emergence of the English "reciprocity" in the mid-eighteenth century, see the etymologies in Walter W. Skeat, An Etymological Dictionary of the English Language (Oxford: Clarendon, 1910), 503; Robert K. Barnhart, The Barnhart Concise Dictionary of Etymology (New York: HarperCollins, 1995), 641. The first appearance in English is attributed to William Blackstone. In his 1766 Commentaries of the Laws of England (London, 1765-69), he argued that contracts cannot legally exist without at least some degree of exchange, or "reciprocity," between the two contracting parties: "Any degree of reciprocity will prevent the pact from being nude" (2:445); cited in Sir James A. H. Murray, The Oxford English Dictionary, 10 vols. (Oxford: Clarendon, 1933), 8:243.

18. Several nineteenth-century dictionaries and philosophical tracts take "fraternité" to be a synonym for "réciprocité." See, for example, Pierre Larousse's definition: "Réciprocité et mutualité ou mutualisme, solidarité et fraternité sont, pour ainsi dire, des synonymes." Dictionnaire universel du XIXe siécle, 17 vols. (Paris: Administration du Grand dictionnaire universel, 1875), 13:779.

19. I would like to thank William Sewell for sharing a partial draft of his work on Forbonnais, which teases out the political economist's "social bond" theory. 
once and the adjective "réciproque" on only 37 pages (across 808 total pages in two volumes). In the French Revolutionary edition, "réciprocité" appears on 7 pages and "réciproque" on 59 (across 912 pages in two volumes)-a dramatic increase. ${ }^{20}$

Another indication of reciprocity's rising importance in the latter half of the eighteenth century can be found in its occurrence in social contract theories. Whereas Jean-Jacques Rousseau's Du contrat social of 1762 contains no occurrence of the term, the social contract of Urbain-Firmin Piault, presented to the National Convention in 1795 during debates about a new constitution, contained 14. For Piault (son of a royal counselor and future mayor of the tenth arrondissement of Paris in the early nineteenth century), reciprocity held republics together: "reciprocity and equality are the bases of the social contract, which bind members individually and collectively." ${ }^{21}$ The use of reciprocity in social contract theories would continue into the nineteenth century. ${ }^{22}$

Eighteenth-century dictionaries failed to signal reciprocity's philosophical importance. The Nouveau dictionnaire universel des arts et des sciences, which was the first to provide an entry for the noun, defined it simply as "of reciprocal quality." 23 Similarly, the Dictionnaire de l'Académie française of 1762 defined it as "the state and character of that which is reciprocal." ${ }^{24}$ The 1768 edition of Dictionnaire royal, français-anglais et anglais-français tiré des meilleurs auteurs flagged its entry with a code indicating "a dubious word or expression ... about which authors are divided." The flag was dropped from later editions, however, suggesting that the term had acquired semantic stability. ${ }^{25}$ The concept's philosophical significance was better registered in nineteenth-century dictionaries. Pierre Larousse's Grand dictionnaire universel du XIXe siècle (1866-88) offered a mini-essay on the subject (see its length in fig. A3), replete with the latest meditations in moral philosophy, political economy,

20. François Véron Duverger de Forbonnais, Élements du commerce: Nouvelle edition, 2 vols. (Paris: Imprimérie de Chaigneau aîné, 1796), 2:260. For the earlier edition, see Forbonnais, Élements du commerce, 2nd ed., 2 vols. (Leyde et se trouve à Paris: Braisson, 1754).

21. Urban-Firmin Piault, Traité de l'esprit des sociétés nationales, suivi d'un Plan de contrat social et de constitution de gouvernement (Paris: Pernier, 1799-1800 [year 8]), 344. (All French translations in this article are the author's.) The "plan" had been presented to the National Convention in Messidor, year 3.

22. Larousse remarked on the term's growing importance in social contract theory in Dictionnaire universel du XIXe siècle, 779.

23. Thomas Dyche, Nouveau dictionnaire universel des arts et des sciences, françois, latin et anglois: contenant la signification des mots de ces trois langues et des termes propres de chaque état et profession: avec l'explication de tout ce que renferment les arts et les sciences, trans. P. E. Pézenas et l'abbé J.-F. Féraud, 2 vols. (Avignon: Chez la Vve de Fr. Girard), 2:310.

24. Dictionnaire de l'Académie française, 17 vols. (Paris: Vve de Bernard Brunet, 1762), 2:553.

25. Abel Boyer, Dictionnaire royal, français-anglais et anglais-français tiré des meilleurs auteurs, 2 vols. (Bâle: Chez Jean Schweighauser, 1768-69), 1:555 (French to English). The editions of 1771, 1773, and 1786 dropped the warning about the term's novelty and imprecision. 
and social contract theory. The fact that no entry for the term appeared in Denis Didérot and Jean Le Rond d'Alembert's Encyclopédie of the mid-eighteenth century but 11 paragraphs were devoted to it in Larousse's Grand dictionnaire universel a century later attests to the dramatic development of the concept. ${ }^{26}$

Taken together, online catalogs and text collections, serial editions of Enlightenment texts, and contemporary dictionaries all show "réciprocité" emerging in the mid-eighteenth century and appearing more frequently thereafter. But what accounts for the concept's emergence? And how did it become a key concept in theories of civil society?

\section{FROM SUBJUGATION TO MORAL EQUALITY}

Before it gained currency during the Enlightenment, "réciprocité" was limited to the jurisprudence on marriage contracts and post- 1648 commercial treaties. ${ }^{27}$ As a legal term, it referred to the claims widows and widowers could make concerning mutual gifts exchanged at the time of matrimony. The term's appearance in commercial treaties was more frequent, though still relatively rare. But it was from this latter usage that its entry into theories of civil society was derived. Perhaps surprisingly from our perspective, "reciprocity" did not initially refer to exchange equivalence or trade balance. It signaled equal standing and mutual recognition-principles that were not to be taken for granted in a hierarchical world fraught with dynastic rivalries and religious strife. For example, the commercial treaty between Catholic Spain and the Calvinist Dutch Republic of 1651, drafted in French, stipulated, "The subjects of Seigneur the King [Spain] will reciprocally hold the same rights and liberties in navigation and traffic, with regard to the Seigneurs of the United Provinces, as their own subjects have with regard to the King of Spain, given the understanding of reciprocity and equality on all sides." ${ }^{28}$ Some historians today question whether the Peace of Westphalia really marked a turning point in international relations toward national sovereignty. ${ }^{29}$ It seems to me, however, that reciprocity in this passage, at the very least, pointed to something new: the presump-

\footnotetext{
26. According to the ARTFL online text collection, "réciprocité" appeared 17 times in the 17 volumes of the Encyclopédie, even though it did not receive an entry.

27. The Making of the Modern World text collection shows only 10 occurrences for "réciprocité" between 1600 and 1730. All refer to commercial treaties. A writer in 1778 acknowledged this etymology in qualifying his use of the term with the phrase, "pour parler le langage de nos vieux traités" in Louis Gabriel, comte du Buat, Les maximes du gouvernement monarchique, pour servir de suite aux Éléments de la politique, 4 vols. (London: n.p., 1778), 1:20.

28. Theophraste Renaudot, ed., Recueil des Gazettes nouvelles, ordinaires et extraordinaires (Paris: Du Bureau d'Adresse, aux Galleries du Louvre, devant la rue S. Thomas, 1651), 59.

29. For revisionist interpretations of the Peace of Westphalia, see Andreas Osiander, "Sovereignty, International Relations, and the Westphalian Myth," International Organization 55, no. 2 (Spring 2001): 251-
} 
tion of equal standing and moral equality among sovereigns of different faiths and political orders. The symmetry extended to merchants as well. Those living in an ally's jurisdiction were to receive the same "rights and liberties" (privileges) as the ally's domestic traders. In early uses of "reciprocity," then, mutual recognition of equal standing trumped considerations of rank, religion, and regime type.

Reciprocity appeared more frequently with the rise of doux commerce in the mideighteenth century. Doux commerce-the theory that commerce civilizes by strengthening bonds of utility and sentiment-imbued reciprocity with philosophical and sociological significance. ${ }^{30}$ Forbonnais spearheaded this use in the 1750 s, we have seen, but the trend continued. By the 1770s and 1780s, it was common to imagine foreign and domestic relations adhering to the same principle: "Reciprocity is as necessary in relations between nations as it is in relations between individuals," propounded a French political economist in 1785, at the height of free-trade negotiations after the American War of Independence. ${ }^{31}$ The view was echoed during the French Revolution. "All great laws ... of trade and commerce, whether with respect to the intercourse of individuals or nations," insisted Thomas Paine in Rights of Man, "are laws of mutual and reciprocal interest." 32 The moral and economic came together in reciprocity. Stock phrases such as "reciprocity of goods, "of services," "of

87; Benno Teschke, The Myth of 1648: Class, Geopolitics, and the Making of Modern International Relations (London: Verso, 2003). A nineteenth-century discussion of reciprocity's origins traces the concept back to the Treaty of Utrecht (1713); see Freeman Hunt, "American Reciprocity and British Free Trade," Hunt's Merchants' Magazine and Commercial Review, 23, no. 4 (1850): 415. Examples of "réciprocité" in discussions of international trade after the Treaty of Utrecht include the "avertissement" in Traité de commerce, navigation et marine, entre La France, et les villes Anséatiques: Conclu à Paris le 28 septembre 1716 (Paris: Collombat, 1717); and Charles-Philippe, vicomte de Patin, Le commerce maritime fondé sur le droit de la nature $\theta$ des gens, sur l'autorité des loix civiles $\theta$ des traitez de paix, $\theta$ rétabli dans sa liberté naturelle traduit du Latin de M. Pattyn, augmenté e enrichi des notes de l'auteur dans cette edition (Malines: Chez Laurent Vander Elst, 1727), 108.

30. The historical literature on doux commerce is vast. The seminal work on the topic is Hirschman, Passions and the Interests. For further on doux commerce, see Daniel Gordon, Citizens without Sovereignty: Equality and Sociability in French Thought, 1670-1789 (Princeton, NJ: Princeton University Press, 1994); David A. Bell, The First Total War: Napoleon's Europe and the Birth of Warfare as We Know It (Boston: Houghton Mifflin, 2007), 52-83; Paul Cheney, Revolutionary Commerce: Globalization and the French Monarchy (Cambridge, MA: Harvard University Press, 2010). For helpful references to this vast literature, see the bibliographies in Shovlin, Political Economy of Virtue; Anoush Fraser Terjanian, Commerce and Its Discontents in Eighteenth-Century French Political Thought (Cambridge: Cambridge University Press, 2013).

31. Anonymous, Réponse à la brochure intitulée Le pour et le contre (n.p., 1785), 26. The phrase was repeated but with "sovereigns" in the place of "nations" in a publication of the same year: Jean-Baptiste Briatte, Étonnement de l'Europe ou Examen des différens entre S. M. I. et la République des Provinces Unies (Frankfurt: n.p., 1785), 68. Another example of reciprocity as a natural law applying to individuals, societies, and nations appears in M. Le Trône [Guillaume-François Le Trosne], De l'administration provincial et de la réforme de l'impôt, 2 vols. (Basle: se trouve à Paris chez Pierre J. Duplain, 1788), 1:57n.

32. Thomas Paine, Rights of Man, Common Sense, and Other Political Writings, ed. Mark Philp (1791; Oxford: Oxford University Press, 2008), 216. 
resources," "of good deeds, "of respect," and "of sentiments" became standard fare in philosophical treatises and often appeared together. ${ }^{33}$ "The reciprocity of services and respect among the Romans," asserted a philosopher seeking the ancient origins of modern law, "was so precious among the Romans ... that it bound Patricians and Plebeians; it bound the whole Empire together." ${ }^{34}$

This fusion of the moral and economic in the concept of reciprocity reveals a paradigmatic shift in notions of obligation from subjugation to moral equality. Prior to this shift, the use of coercion to enforce obligations-obedience, deference, tribute, taxes-was considered neither unusual nor necessarily evil. Violence, or the threat of it, was seen as the common means for reaching agreements and maintaining order. ${ }^{35}$ As Hobbes observed: "for the Laws of Nature . . . , unto themselves, without the terror of some power to cause them to be observed, are contrary to our natural passions. . . Covenants without the sword are but words." ${ }^{36}$ This view began to change in the late seventeenth century. In this early period of the Enlightenment, as Keith Baker has noted, "subjugation [was] replaced as a principle of order by the moral obligations men owe one another as rational creatures and members of a common human species." ${ }^{37}$ John Locke put the view even more succinctly: "It is not fear of punishment that binds us, but our determination of what is right." 38

This shift from hierarchy and subjugation to moral equality and reciprocity is discernible across the early modern period. In his 1610 petition calling for the expulsion of the Jesuits after the assassination of Henry IV (perpetrated by a Jesuit priest), the lawyer Pierre de la Martelière rejected reciprocity as a basis for political

33. Several of these stock phrases appeared as examples under the entry for "réciprocité" in the Dictionnaire de l'Académie française of 1762 . Numerous treatises on political economy and civil society combined them as well.

34. Anonymous, Les loix puisées chez les grecs, développées par les romains, aujourd'hui base du droit public et civil des nations policées, 2 tomes (Paris: Babuty fils, 1765), 1:16.

35. For the perceived normalcy of war before the Enlightenment, see Bell, The First Total War, 5; for the perceived normalcy of coercion in governing, see Arno J. Mayer, The Furies: Violence and Terror in the French and Russian Revolutions (Princeton, NJ: Princeton University Press, 2000), 71.

36. Thomas Hobbes, Leviathan, or the Matter, Forme and Power of a Common-wealth, Ecclesiastical and Civil (London: Andrew Crooke, 1651), 103.

37. Keith M. Baker, "Enlightenment and the Institution of Society: Notes for a Conceptual History," in Main Trends in Cultural History: Ten Essays, ed. Willem Melching and Wyger Velema (Amsterdam: Rodopi, 1994), 110. Baker is summarizing Louis Dumont's thesis in Homo Equalis: genèse et épanouissement de l'idéologie économique (Paris: Gallimard, 1977). For another overview of Dumont's thesis, which also stresses the shift from subjugation to morality, see Marcel Gauchet, "De l'avènement de l'individu à la découverte de la société," Revue européenne des sciences sociales 22, no. 68 (1984): 451-63, esp. 455.

38. Cited in J. B. Schneewind, "Locke's Moral Philosophy," in The Cambridge Companion to Locke, ed. Vere Chappell (Cambridge: Cambridge University Press, 1994), 214, from Locke's Essays on the Law of Nature. 
obligations: "There is nothing more natural regarding obligations than that the first [obligation], and more precise than reciprocity, is that people are obliged to be faithful and obedient to their Prince, while the Prince is expected to protect his subjects." ${ }^{39}$ Contrast that statement with one made a century and a half later by Claude-Joseph de Ferrière, a jurist and admirer of Roman law. Far from dismissing reciprocity, Ferrière took it to be a "general law," one premised on moral equality: “Just as a Vassal who mistreats his Seigneur loses his fief, it is just, by the law of reciprocity, that the Seigneur who mistreats his Vassal, and who becomes his tyrant, should also lose his rights with regard to him." ${ }^{40}$ To be sure, hierarchy is not altogether absent-we still have lords and vassals—but the "law of reciprocity" placed mutual obligations on more egalitarian terrain.

Another sign of subjugation's decline and reciprocity's rise appears in an abridged 1755 edition of Jean Bodin's sixteenth-century Les six livres de la République. Retitled Abrégé de la République de Bodin, the new edition was substantially revised by a magistrate from Bordeaux and member of the Royal Council, Jean-Charles de Lavie. In his preface, Lavie admitted to having taken great liberties in restructuring Bodin's text. It appears he took great liberties with the content as well. For unlike Bodin, who never used the term, Lavie put reciprocity at the heart of the social order: "Mutual assistance is an indispensable obligation in every civil society; as such, civil society forms a single moral individual. Union can only subsist through reciprocity. If one violates it, society ceases." ${ }^{41}$ For Lavie, reciprocity was the sine qua non of society. And society, in his view, was a homogeneous moral totality, "a single moral individual." ${ }^{42}$ Not that he eschewed inequalities; he believed they were inevitable. But he attributed them to the uneven distribution of talents and strengths, not to any ontology of rank (caste, orders, estates). Inequalities were incidental, not essential, in civil society. Lavie's reasoning exemplifies what Pierre Rosanvallon describes as the "secondarization" of social differences during the Enlightenment. ${ }^{43}$ Social differences were acknowledged but treated as accidents of nature or history, which in no way impinged on the fundamental premise of moral equality. ${ }^{44}$ This very premise

39. Pierre de La Martelière, Plaidoyé de Me. Pierre de La Martelière, ... faict en Parlement. . . Les dix-septiesme et dix-neufiesme décembre mil six cens unze, pour le recteur et université de Paris, . . contre les jésuites, demandeurs et requérans l'enthérinement des lettres patentes par eux obtenuës de pouvoir . . enseigner en ladite université (Paris: Chez Jean Petit-Pas, 1612), 41.

40. Claude Joseph de Ferrière, Dictionnaire de droit et de pratique, contenant l'explication des termes de droit, d'ordonnances de coutumes et de pratique: Avec les juridictions de France, 2 vols. (Paris: Saugrain fils, 1755), 2:104.

41. Charles de Lavie, Abrégé de la République de Bodin, 2 vols. (London: Jean Nourse, 1755), 2:267.

42. Ibid.

43. Pierre Rosanvallon, La société des égaux (Paris: Le Seuil, 2013), 73-88.

44. Ibid. According to Rosanvallon, in the nineteenth century, science would reessentialize social differences to justify social hierarchies (135-46). Another example of this secondarization of social differences 
appears in Lavie's invocation of the Golden Rule, which he formulated positively ("do unto others") and negatively ("do not do unto others"). "All moral and civil laws," he insisted, "are derivations of these twin principles." 45

None of this appears in Bodin's original text. On the contrary, the sixteenthcentury editions stressed subordination, not reciprocity. Bodin's solution to the problem of vagrancy, for example, was not "mutual aid," as Lavie would have it, but expulsion. Vagrants- “beasts and trash," in his view-were to be chased from the republic by armies. ${ }^{46}$ Bodin advised treating others according to rank and not, as Lavie believed, according to how one wished to be treated (the Golden Rule). ${ }^{47}$ For Bodin, hierarchy, not reciprocity, dictated the terms of generosity: "The laws of liberality command that one consider carefully to whom one gives, how much one gives, when and where, for what ends, and the power of the one who gives." ${ }^{48}$

The concept of reciprocity thus grew out of changing ideas about social obligation. As subjugation gave way to moral equality, reciprocity came to be seen as the essence of social bonds. But it was a largely empty category. It may have implied moral equality and mutual recognition, but the specific kinds of exchanges it referred to could vary according to one's political and philosophical commitments. Such commitments came increasingly into conflict with each other toward the end of the century, especially after 1789. Before considering those conflicts, we will examine capitalism's role in accelerating the term's use in the latter half of the eighteenth century.

\section{CAPITALISM AND THE REIMAGINING OF SOCIAL BONDS}

Moral equality was thus a conceptual precondition for the emergence of réciprocité. But what accounts for the sudden explosion of the concept in French philosophy after 1750? The most obvious factor was the explosion of print. More lenient

during the Enlightenment appears in Gabriel, le comte Du Buat, Les maximes du gouvernement monarchique, 1:2: "I have proven that men are essentially equal, and that the sole consequence of this equality is the equal right to happiness; but from this primitive equality derives the necessity of an inequality of condition, of rights, of advantages, and of prerogatives, which is not an iniquity, as long as they correspond to accidents ... such as birth, fortune, and education."

45. Lavie, Abrégé de la République de Bodin, 1:228.

46. Jean Bodin, Les six livres de la République, 6 vols. (Geneva: Estienne Gamonet, 1629), 5:762.

47. Lavie, Abrégé de la République de Bodin, 1:228.

48. Bodin, Les six livres de la République, 5:747. Early modern theorists of social order, such as Bodin and the early seventeenth-century jurist Charles Loyseau, did use the adjective "réciproque," but it did not convey the principle of moral equality. As in La Martelière's statement cited above, different obligations pertained to different ranks. For Loyseau, harmony, not equivalence, was the operative principle of obligation, and he rejected equality outright: "We cannot live together in a condition of equality, but of necessity it must be that some command and others obey." A Treatise on Orders and Plain Dignities, ed. and trans. Lloyd A. Howell (Cambridge: Cambridge University Press, 1994), 5. 
censorship policies in the late 1740s, together with rising literacy, spurred the publishing industry, offering more occasions for the term to appear. ${ }^{49}$ But a print boom explains only the absolute increase in the term's use (fig. A5), not its relative increase (fig. A4). Why did writers invoke réciprocité more often when they picked up their pens?

A prosopography of the hundreds of writers who used the term in the eighteenth century will not shed much light on the matter. They were too diverse. Some were wealthy, others modest; some supported state centralization, others feudalism; some invoked reciprocity to justify free markets, others (albeit fewer) to justify privilege and even forms of protosocialism. Moreover, no writer before the nineteenth century, with the exception of the idiosyncratic Rétif de la Bretonne (discussed below), offered any sustained reflection on the term. Reciprocity entered French philosophy without much exposition or debate. Writers assumed their readers knew what it meant, even as they gave it different meanings.

To explain the rise of reciprocity talk after 1750, we must consider the broader context. A growing preoccupation with political economy, I believe, was a key factor. Reciprocity appeared often in tracts on commerce and finances, which proliferated in the Old Regime's final decades. But these tracts also advanced theories about civil society, which raises the question: Why were political economists so compelled to connect the two? Why did they try to tether economic reciprocity ("la réciprocité des biens et des services") to moral reciprocity ("la réciprocité des sentiments et des bons offices" and "la réciprocité des droits et des devoirs")?

The growth of capitalism, I believe, goes a long way in explaining these efforts. It spurred theorizing about social bonds-and thus reciprocity-by conditioning individuals to see others differently (as civil equals) and to feel about others differently (as fellow humans worthy of empathy and assistance). In radically transforming social relations, capitalism also stoked anxieties about the social order, thereby prompting efforts to better understand the nature of social bonds and how to strengthen them. Reciprocity talk expressed these views, sentiments, and anxieties.

Capitalism made civil equality thinkable by replacing the "Great Chain of Being" with horizontal conceptions of society. In his study of the booming genre of newssheets in the late Old Regime, Colin Jones locates the emergence of the civic-

49. For the post-1750 print boom, see Henri-Jean Martin, "Une croissance séculaire," in Histoire de l'édition française. 2: Le livre triomphant, 1660-1830, ed. Roger Chartier and Henri-Jean Martin (Paris: Fayard, 1990), 113-27; for the loosening of censorship restrictions and the creation of "tacit permissions" under the directorship of Guillaume-Chrétien de Lamoignon de Malesherbes, see Daniel Roche, "La censure," in the same volume, 88-98. For rising literacy rates, see François Furet and Jacques Ozouf, Reading and Writing: Literacy in France from Calvin to Jules Ferry (Cambridge: Cambridge University Press, 1982), 5-58. 
minded consumer: in juxtaposing advertisements and commentary (often conveyed surreptitiously in news columns and book reviews), the newssheets accustomed readers to see themselves and others as enlightened citizens. ${ }^{50}$ Caste was irrelevant in this commercial space, where "compatriots'" were encouraged "to communicate reciprocally among themselves their needs and their thoughts." ${ }^{51}$ William Sewell also finds capitalism spreading notions of civil equality. He sees this occurring in the Parisian promenades such as the Tuileries Gardens and the Palais Royal-quasianonymous commercial spaces where individuals with enough means could sport the latest fashions. Social mingling and conspicuous consumption had the effect of "loosening the link between appearance and status," making civil equality thinkable. ${ }^{52}$ The Declaration of the Rights of Man and of the Citizen of 1789, Sewell concludes, marked the arrival of the abstracted individual created by capitalism: the citizen. $^{53}$

Seeing others as civil equals was one thing; feeling sentimental attachments to them was another. Here, again, capitalism played a role. It was through commercialized culture, especially print and theater, that notions of empathy and civic solidarity were popularized. Melodrama was especially effective in this regard. Commercial theaters performing the new genre sprouted up in Paris, the provinces, and the colonies in the latter half of the eighteenth century. ${ }^{54}$ Several philosophes, notably Denis Diderot, praised melodrama for its didactic value: in summoning spectators to empathize with the trials and tribulations of ordinary individuals, it taught them to make moral judgments. ${ }^{55}$ Melodramatic sensibilities spilled over into mémoires judiciaires, the published trial briefs of some of the greatest causes célèbres of the late Old Regime. As Sarah Maza has shown, these briefs, which became

50. Colin Jones, "The Great Chain of Buying: Medical Advertisement, the Bourgeois Public Sphere, and the Origins of the French Revolution," American Historical Review 101, no. 1 (1996): 25. For the surreptitious insertion of political commentary in late Old Regime book reviews, see Vivian R. Gruder, "Political News as Coded Messages: The Parisian and Provincial Press in the Pre-revolution, 1787-1788," French History 12, no. 1 (1998): 1-24.

51. Jones, "Great Chain of Buying," 25. Jones cites a newssheet from 1777.

52. William H. Sewell, "Connecting Capitalism to the French Revolution: The Parisian Promenade and the Origins of Civic Equality in Eighteenth-Century France," Critical Historical Studies 1, no. 1 (2014): 27.

53. Ibid., 14.

54. Isabelle Martin, Le théâtre de la foire: des tréteaux aux boulevards (Oxford: Voltaire Foundation, 2002); Michèle Root-Bernstein, Boulevard Theater and Revolution in Eighteenth-Century Paris (Ann Arbor, MI: UMI Research Press, 1984). For the spread of theaters in the provinces and colonies in the latter half of the eighteenth century, see Lauren Clay, Stagestruck: The Business of Theater in Eighteenth-Century France and Its Colonies (Ithaca, NY: Cornell University Press, 2013). For spectator demands for more entertaining playbills, see Jeffrey S. Ravel, The Contested Parterre: Public Theater and French Political Culture, 1680-1791 (Ithaca, NY: Cornell University Press, 1999).

55. Sarah Maza, Private Lives and Public Affairs: The Causes Célèbres of Prerevolutionary France (Berkeley: University of California Press, 1993), 61. 
bestsellers in the 1770s and 1780s, raised awareness of aristocratic despotism by prompting citizen-readers to identify with the plight of ordinary victims. Lynn Hunt locates the rise of civic empathy in epistolary novels, such as Samuel Richardson's Clarissa (1748) and Rousseau's Julie, ou la Nouvelle Hélö̈se (1762). Reading these novels, she speculates, "had physical effects [emotional responses] that translated into brain changes and came back out as new concepts about the organization of social and political life." ${ }^{56}$ Human rights, she argues, were among the new concepts. So, too, I would argue, was reciprocity - a term often invoked in discussions of rights and duties in the late eighteenth century. ${ }^{57}$

In spreading notions of civil equality and sentiments of civic solidarity, capitalism made reciprocity thinkable and emotionally compelling. But capitalism contributed to reciprocity's rise in still another way. In altering social relations, it stirred up anxieties about the social order, prompting reflection on the nature of social bonds and how to strengthen them. The erosion of status through commercialized fashion was one source of anxiety, expressed in the much-studied debate over luxury. ${ }^{58}$ But capitalism's disruptive dynamics went deeper. In exacerbating wealth inequality, social precariousness, and indebtedness, capitalism strained social relations. The first two of these problems-wealth inequality and social precariousnesshave been well documented. ${ }^{59}$ The latter problem-indebtedness-has recently be-

56. Lynn Hunt, Inventing Human Rights: A History (New York: Norton, 2006), 33.

57. I have identified no fewer than 60 eighteenth-century texts in which "réciprocité" appears in discussions of rights and duties. To take a prominent example, albeit in English: Thomas Paine defended the Declaration of the Rights of Man and of the Citizen of 1789 from criticism that it omitted duties by arguing, "a Declaration of Rights is, by reciprocity, a Declaration of Duties;" in Rights of Man (1791; London: Penguin, 1985), 114.

58. Shovlin, Political Economy of Virtue; Sarah Maza, "Luxury, Morality, and Social Change in Prerevolutionary France," Journal of Modern History 69, no. 2 (1997): 199-229; Colin Jones and Rebecca Spang, "Sans-Culottes, Sans Café, Sans Tabac: Shifting Realms of Necessity and Luxury in Eighteenth-Century France" in Consumers and Luxury: Consumer Culture in Europe, 1650-1850, ed. Maxine Berg and Helen Clifford (Manchester: Manchester University Press, 1999), 37-62; Jeremy Jennings, "The Debate About Luxury in Eighteenth- and Nineteenth-Century France," Journal of the History of Ideas 68, no. 1 (January 2007): 79105.

59. For a synthesis of historical work on rising inequality and social precariousness in eighteenthcentury France, see Jean-Pierre Jesenne, "The Social and Economic Crisis in France at the End of the Ancien Régime," in A Companion to the French Revolution, ed. Peter McPhee (West Sussex: Wiley Blackwell, 2013), 24-41; Jack A. Goldstone, "Demography," in The Oxford Handbook of the Ancien Régime, ed. William Doyle (Oxford: Oxford University Press, 2012), 201-18. The transformation of communal bonds in Old Regime France is discussed in David Garrioch, Neighborhood and Community in Paris, 1740-1790 (Cambridge: Cambridge University Press, 1986); for growing geographical mobility, see Daniel Roche, Humeurs vagabondes: De la circulation des hommes et de l'utilité des voyages (Paris: Fayard, 2003). Throughout the eighteenth century, the French countryside experienced low economic growth, much of which was either siphoned off in taxes to pay for commercial wars or absorbed by a growing (and increasingly transient) population. Economic growth was high in port cities, but the wealth did not penetrate into the interior (Paris excepted); see Philip 
gun attracting the attention of historians. ${ }^{60}$ Their studies show us a society shot through with indebtedness, from the countryside to Versailles. The development of commercial capitalism spurred the development of financial capitalism, saddling both the state and society with greater debts. Costly wars of commercial expansion, especially the Seven Years' War (1756-63) and the American War of Independence (1775-83), drove the regime to the brink of bankruptcy by the late 1780s. Yet, individuals were also mired in debts as they came to rely increasingly on credit for necessities (food, apprenticeships, dowries) and status items (luxuries, seigneuries, venal offices, titles). Financial innovations of the period made loans easier to obtain but not necessarily easier to service, especially during economic downturns. ${ }^{61}$

As debts grew, debtors tried to foist their burdens onto inferiors. The crown did so by curtailing fiscal privileges and combing the countryside for taxes, often with troops. The results were explosive: while elites cried despotism and mounted resistance through the parlements (France's sovereign courts), villagers increasingly rebelled. ${ }^{62}$ To deal with their own financial burdens, elites tried to squeeze more wealth from their seigneuries. They reimposed long neglected feudal dues and consolidated their direct landholdings by seizing the parcels of increasingly insolvent tenants. ${ }^{63}$ Periodic attempts to liberalize the grain trade (to increase agricultural pro-

T. Hoffman, Growth in a Traditional Society: The French Countryside, 1450-1815 (Princeton, NJ: Princeton University Press, 1996).

60. Sonenscher, Before the Deluge; Fontaine, L'économie morale; Clare Haru Crowston, Credit, Fashion, Sex: Economies of Regard in Old Regime France (Durham, NC: Duke University Press, 2013); David Stasavage, Public Debt and the Birth of the Democratic State: France and Great Britain, 1688-1789 (Cambridge: Cambridge University Press, 2003).

61. For financial innovations, see Philip T. Hoffman, Gilles Postel-Vinay, and Jean-Laurent Rosenthal, Priceless Markets: The Political Economy of Credit in Paris, 1660-1870 (Chicago: University of Chicago Press, 2000).

62. Political struggles during the late Old Regime were largely about the crown's efforts to impose taxes on elites-a story well described by all general overviews of the Old Regime. For a concise synthesis, see Gail Bossenga, "The Financial Origins of the French Revolution," in From Deficit to Deluge: The Origins of the French Revolution, ed. Thomas E. Kaiser and Dale K. Van Kley (Stanford, CA: Stanford University Press, 2011), 37-66. For eighteenth-century successes in taxing privileged nobles, see Michael Kwass, Privilege and the Politics of Taxation in Eighteenth-Century France: Liberté, Égalité, Fiscalité (Cambridge: Cambridge University Press, 2000). For rising rebelliousness in the late eighteenth century, see Jean Nicolas, La Rebellion française: Mouvements populaires et conscience sociale (1661-1789) (Paris: Le Seuil, 2002).

63. For the consolidation of land tenures by wealthier peasants, who took over the tenures of insolvent ones, and for the incorporation of peasant tenancies into landlord property, see Goldstone, "Demography," in The Oxford Handbook of the Ancien Régime, ed. William Doyle (Oxford: Oxford University Press, 2012), 213; for the shift from subsistence to speculative farming, the privatization of the commons, and large-scale farming, see Peter Jones, "Agriculture," in the same anthology, 244-46; see also P. M. Jones, The Peasantry in the French Revolution (Cambridge: Cambridge University Press, 1988), 8, 31; and Anatoli Ado, Paysans en Révolution: Terre, pouvoir et jacquerie, 1789-1794 (Paris: Société des Études robespierristes, 1996), 78-82. For a chronologically broader discussion of peasant and elite indebtedness throughout the early modern period, see Fontaine, L'économie morale, 48-100. 
ductivity and, consequently, tax revenues) made matters worse, polarizing communities, dividing authorities, and sparking acrimonious debate in the Republic of Letters. ${ }^{64}$ Little wonder there was so much theorizing about social bonds in the latter half of the eighteenth century. Those bonds were manifestly fraying. ${ }^{65}$

But how did reciprocity emerge as the perceived antidote to these ills? Because philosophers did not explain their affinity for the concept after 1750, the answer requires some theorizing. A fruitful starting point is Kojin Karatani's The Structure of World History: From Modes of Production to Modes of Exchange-a recent work of historical philosophy that brings morality and economic exchange together into an analysis of social orders. ${ }^{66}$ According to Karatani, at certain times in history, two modes of exchange, each with its own social and moral logic, have come into sharp tension with each other: redistribution and commodity exchange. Redistribution involves procuring resources, usually through war and taxes, and selectively distributing them through hierarchies. In redistributive orders, politics and the economic interests are intertwined in a culture of clientage and subjugation. Advancement requires currying the favor of patrons. The commodity-exchange system differs. Although it depends on the redistributive state, merchants prefer to operate on the basis of consent, not subjugation. Commodity exchange favors property rights and voluntary contracts between moral and legal equals. Although commodity exchange may appear to be more egalitarian, Karatani (drawing on Marx) argues that, in its global capitalist form, it produces hierarchies of wealth. ${ }^{67}$

Though historically interdependent (merchants have relied on the state's money, military, and courts), the redistributive state and global commerce pull in different directions. From the standpoint of commodity exchange, the redistributive state can appear obstructive, arbitrary, and corrupt. It unduly politicizes economic ex-

64. For free-market grain policies as an attempt to cope with regime debt, see Eugene Nelson White, "Was There a Solution to the Ancien Regime's Financial Dilemma?" Journal of Economic History 49, no. 3 (September 1989): 545-68. Increased taxation and speculation on future tax revenues outpaced increases in agricultural productivity; see Hoffman, Growth in a Traditional Society. For polarization of authorities and society over the liberalization of the grain trade, see Steven Laurence Kaplan, Bread, Politics, and Political Economy in the Reign of Louis XV, 2 vols. (The Hague: Martinus Nijhoff, 1976); Cynthia A. Bouton, The Flour War: Gender, Class, and Community in Late Ancien Regime France (University Park: Pennsylvania State University Press, 1993); Dena Goodman, The Republic of Letters: A Cultural History of the French Enlightenment (Ithaca, NY: Cornell University Press, 1996), chap. 5.

65. Emma Rothschild argues that theories of "economic sentiments," notably those of Adam Smith and Marquis de Condorcet, were a response to the uncertainties and instabilities of the late eighteenth-century commercial revolution; Economic Sentiments, 236-52.

66. Kojin Karatani, The Structure of World History: From Modes of Production to Modes of Exchange, trans. Michael K. Bourdaghs (Durham NC: Duke University Press, 2014).

67. This is because in global capitalism, surplus value is derived through exchanges across different systems of value. Ibid., 182-208. 
change (better left to markets) and constrains property and trade. From the standpoint of redistribution, commercial freedom produces selfishness, wealth imbalances, and social fragmentation. Both modes of exchange produce hierarchies: in redistribution, those hierarchies are based on status; in commodity exchange, they are based on wealth. Karatani treats these modes of exchange as ideal types. He acknowledges that they coexist in reality, albeit in different proportions at different times-but proportions matter. His main point is that when global commerce comes to predominate, as it did in the eighteenth century, it puts pressure on the redistributive state, creating conditions for a moral, social, and political crisis.

How does reciprocity fit into all of this? Karatani argues that when the advocates of global commerce begin seeing the redistributive state as a hindrance but also when anxieties about capitalism begin to rise, the friction between the two modes of exchange-between commerce and redistribution-sparks efforts to transcend both. How? Through the revival of a repressed mode of exchange stretching back to clan societies: reciprocity (gifts and countergifts among relative equals). This "return of the repressed" (he draws on Sigmund Freud) ${ }^{68}$ recasts archaic reciprocity in a higher, religious-like dimension. In the eighteenth and nineteenth centuries, the return of repressed reciprocity took the forms of nationalism and socialism. The nation and worker associations were seen as egalitarian spheres of reciprocity-as "imagined communities" (he draws on Benedict Anderson) ${ }^{69}$ of exchange and solidarity among equals. Patriotic self-sacrifice and mutualism represented moral alternatives to feudal rent seeking and capitalist exploitation. Crucially, these forms of "reciprocity-inhigher-dimension" ${ }^{70}$ exist in the imagination; social orders founded on them inevitably relapse into redistributive and commercial modes of exchange-until the friction between the two builds again, reigniting the "reciprocal" imagination. The modern era can be seen as an ongoing struggle between global capitalism and the redistributive state, with periodic surges of reciprocity in the forms of nationalism and socialism. $^{71}$

The Freudian element of Karatani's theory-the return of repressed reciprocity stretching back to early clan societies - can only be speculative, but it chimes with the historical evidence. Eighteenth-century philosophers themselves looked to clan societies for examples of reciprocity. “The laws of nomadic peoples are very simple:

68. Ibid., 56

69. Ibid., 27.

70. Ibid., 8.

71. Karatani worries that this modern cycle may be coming to an end because capitalism can no longer count on unlimited labor and natural resources being fed into it from outside the system. Consequently, "the world in which commodity exchange is predominant will regress to a world based on plunder and violent appropriation carried out by the [redistributive] state." Ibid., 284. 
they consist only of a kind of martial order and the law of reciprocity," speculated Rétif de la Bretonne, in a pithy formulation of a common conjecture. ${ }^{72}$ Political economists often hypothesized about the nature of primitive societies in efforts to establish the general law of reciprocity. True, they did so usually to justify commercial capitalism, which may seem to contradict Karatani's claim that they did so to transcend it. But justifying commercial capitalism while trying to transcend its iniquities (or treating those iniquities as secondary and incidental) is possible within his framework.

Karatani's theory also accords with what we know about Old Regime France. It is not difficult to find evidence of the friction between the redistributive state and commercial capitalism in the recent historiography. It appears in studies of contemporary debates over the colonial exclusive, which pitted colonial free traders against metropolitan mercantilists; over attempts to liberalize the grain trade, which divided authorities and communities; over monopolistic trading companies, such as the French Compagnie des Indes, which were chartered and suppressed repeatedly across the century; over attempts to abolish the guilds and corporations, which sparked protests and revolts; and over the liberal Anglo-French Commercial Treaty of 1786, which, in opening up France to cheap British imports, nearly annihilated France's nascent manufacturing, provoking demands for subsidies and protections. ${ }^{73}$ What Karatani helps us see is how this friction sparked the reciprocal imagination, and how reciprocity talk, in turn, fed into patriotic and eventually socialist

72. Nicolas-Edme Rétif de la Bretonne, Le Thesmographe, ou Idées d'un honnête homme sur un projet de règlement proposé à toutes les nations de l'Europe pour opérer une réforme générale des loix; avec des notes historiques (Paris: Maradan, 1789), 195. See also Anonymous, Les loix puisées chez les grecs, 1:154-55: “Man was the only animal made for society, given his gift for conducting commerce with his fellowmen; ... fear compelled him to join with a small number [of others], and the aid he received subjected him to duties ... , from which the reciprocity of resources was derived." For the role of primitive societies in conjectural histories of the Scottish Enlightenment, see H. M. Hopfl, "From Savage to Scotsman: Conjectural History in the Scottish Enlightenment," Journal of British Studies 17, no. 2 (Spring 1978): 19-40.

73. For debates over the colonial exclusive, see Cheney, Revolutionary Commerce. Like Karatani, Cheney sees the concept of "the nation" being mobilized on both sides of the colonial-metropolitan debate over trade-the nation served efforts to transcend tensions between monopolies and commercial freedom. For debates over the liberalization of the grain trade, see Kaplan, Bread, Politics, and Political Economy; Bouton, Flour War; Judith A. Miller, Mastering the Market: The State and the Grain Trade in Northern France, 17001860 (Cambridge: Cambridge University Press, 1999). For debates over the attempt to suppress the guilds and corporations in the 1770s and again in the 1790s, see Jean-Pierre Hirsch, Les deux rêves du commerce: Entreprise et institution dans la région lilloise (1780-1860) (Paris: École des Hautes Études en Sciences Sociales, 1991); Philippe Minard, La fortune du colbertisme: État et industrie dans la France des Lumières (Paris: Fayard, 1998). For debates over the state-sanctioned Compagnie des Indes, see Terjanian, Commerce and Its Discontents, 137-81. For debates about the Franco-British Commercial Treaty of 1786, see Charles Walton, "The Fall from Eden: The Free-Trade Origins of the French Revolution," in The French Revolution in Global Perspective, ed. Suzanne Desan, Lynn Hunt, and William Max Nelson (Ithaca, NY: Cornell University Press, 2013), $44-56$. 
discourses. What Karatani does not see, however, is that early reciprocity talk also fed into discourses about commercial society-that reciprocity helped justify freemarket capitalism before becoming the latter's "antithesis and alter ego" after the French Revolution.

Karatani's theory also helps us make sense of periodic surges of réciprocité across the modern era. Google Ngram Viewer (fig. A4) shows three frequency spikes for the term (aside from the statistically insignificant spikes of the early eighteenth century). The first significant spike occurred in the latter half of the eighteenth century, the second between 1830 and 1848, and the third in the 1920s and 1930s. The timing of these spikes is suggestive. They occurred when heady free-market ideologies and advances in capitalism (commercial, industrial, and financial) met with heightened demands for social protections and wealth redistribution, often in the throes of economic change and crisis. Reciprocity talk might therefore represent a conceptual countermovement to free-market capitalism-a way of imagining harmonious social relations in the face of widening wealth inequalities and disruptive socioeconomic change. The spikes also appear around revolutionary moments: the late eighteenth-century commercial and democratic revolutions, the industrial and political revolutions between 1830 and 1848, and the reverberations of the Russian Revolution of 1917, which fed into socialist and fascist movements, especially after the financial crisis of 1929. Given this historical pattern, one wonders whether the rise of reciprocity talk in anglophone scholarship since the 1980s reflects a conceptual countermovement against neoliberal globalization. Karatani's theory suggests that a resurgence of the reciprocal imagination would find expression in nationalist and socialist discourses-a phenomenon we have witnessed since the global financial crisis of 2008.

In sum, the history of the concept of reciprocity appears to be intertwined with the history of capitalism. The advent of commercial and financial capitalism in the eighteenth century generated ideas, sentiments, and anxieties that made reciprocity a compelling concept for reimagining social bonds. But beyond its premise of moral equality and its connotations of sentimental solidarity, what did reciprocity mean? What kinds of exchanges did it refer to? And how did it go from justifying economic liberalism to becoming capitalism's "antithesis and alter ego"?

\section{BARTER AND THE GOLDEN RULE}

In his Dictionnaire universel du XIXe siècle, Larousse defined reciprocity in two ways. On the one hand, it referred to the barter. "Reciprocity," he explained, "is the exchange of goods and services on the basis of perfect, absolute equality." This "natural" form of exchange differed from capitalism in its exclusion of profit making. "In 
reciprocity, profit cannot exist because exchanges occur at cost price." ${ }^{74}$ But reciprocity was not merely utilitarian; it was also, he argued, an application of the Golden Rule, "the well-known precept: do unto others as you would wish to be done to you." He observed, albeit with skepticism, that reciprocity was widely taken to be synonymous with fraternity-those "charitable sentiments of altruism [that] dominate the economy precisely because society is considered a family." Fusing these two understandings together (utility and altruism), he concluded that reciprocity boiled down to the principle "to each according to his need."

Larousse's combining of barter and the Golden Rule into the concept of reciprocity stretched back to the eighteenth century. It is discernible in some of the earliest uses of the term. It reflects the effort to moralize economic productivity by conflating it with generosity toward one's fellow humans. In a treatise on education in 1762, written in anticipation of the Jesuits' expulsion from France (and hence from education), François de Paule Combalusier, chair of pathology at the University of Valence, called for teaching children "that all men are brothers, that they are equal by their nature, that they are essentially tied by the reciprocity of goods and services, and that the greatest among them is the most charitable." ${ }^{75}$ In juxtaposing economic exchange and charity, Combalusier was no doubt trying to fuse them in the minds of children. The two also overlapped in a posthumous treatise on moral philosophy of 1754, penned by the outspoken critic of Jansenism and enemy of the philosophes Abbé François Ilharat de La Chambre: "Whoever thinks that men should be useful to each other but does not himself work for others' happiness is an outrageous imbecile. Such is the constitution of humanity: it consists of and is maintained by the reciprocity of the same [degree of] assistance."76 To produce and exchange was to extend aid and assistance.

The question of whether aid and assistance (secours) sprang from sympathy or self-interest—or a combination of the two-was a matter of much philosophical speculation throughout the eighteenth century, from Mandeville to Condorcet, passing by Rousseau, the physiocrats, and Smith. ${ }^{77}$ Reciprocity encompassed both sides of this debate. It referred to self-interested exchanges (of "reciprocal utilities") and to civic generosity. But the two conceptions were not always given equal stress. The physiocrats, seeking to liberalize the Old Regime's economy, emphasized the

74. Larousse, Dictionnaire universel du XIXe siecle, 13:779.

75. François de Paule Combalusier, Mémoire de l'université sur les moyens de pouvoir à l'instruction de la jeunesse et de la perfectionner (n.p., 1762), 6.

76. François Ilharat de La Chambre, Abrégé de la philosophie, ou Dissertations sur la certitude humaine, la logique, la métaphysique, et la morale, 2 vols. (Paris: Joly de Fleury, Jean-Omer, 1754), 2:27.

77. Pierre Force, Self-Interest before Adam Smith: A Genealogy of Economic Science (Cambridge: Cambridge University Press, 2003). 
former. "Nature's aim is to link men together through bonds of reciprocal utility," insisted Pierre-Paul Le Mercier de la Rivière, a popularizer of physiocracy, in his $L^{\prime}$ ordre naturel et essentiel des sociétés of $1767 .{ }^{78}$ For him, the moral framework for economic exchange was not noble generosity or Christian charity but "rights and duties." Individuals had the natural right of private property, to exchange their property as they pleased, but they also had the natural duty to be productive and respect others' property. It was in recognizing one's duties and the advantages for oneself of "staying united through mutual aid" - by being economically productive- that "social bonds were tightened." ${ }^{79}$

Although Le Mercier emphasized balance and utility, he left room in his philosophy for generosity and obligation. To be productive was at once a generous act and the fulfillment of an obligation not to particular individuals but to society as a whole: "It is to society that we are indebted." ${ }^{80}$ Still, at every turn in the argument, Le Mercier pressed generosity and obligation into a balanced system of utility and rational self-interest. His understanding of the parent-child relationship exemplifies this tendency. Although nature may have instilled caring sentiments in parents, the carrying out of parental duties was also achieved "by the contemplation of the need mothers and fathers will have one day for the aid of their children." ${ }^{81}$

Reciprocity runs throughout Le Mercier's L'ordre naturel. All the fundamental aspects of social relations_rights, duties, exchange-adhere to this principle. Balance and moral equality appear everywhere; hierarchy and caste simply do not enter the frame. Le Mercier did not, however, deny the existence of inequalities. But like other philosophers at the time, he secondarized them, attributing them to accidents of nature about which little could or should be done: "the inequality of conditions is the necessary consequence of natural inequalities [of strengths, talents, etc.]; and even if inequality is a factor behind social disorders, it should not be abolished since doing so would require abolishing [private] property, and, hence, society itself." ${ }^{82}$

Other writers invoking reciprocity stressed generosity and obligation over selfinterest and exchange equivalence. In his whimsical Les nuits de Paris in 1789, the irreverent observer of urban life, Rétif de la Bretonne, offered what is the only sustained meditation on the concept I have found for the eighteenth century. In a

78. Pierre-Paul Le Mercier de la Rivière, L'ordre naturel et essentiel des sociétés politiques (London: Chez Jean Nourse et se trouve à Paris, chez Desaint, 1767), 270.

79. Ibid., 437-38.

80. Ibid., 5 .

81. Ibid., 437.

82. Ibid., 29. 
chapter titled "Réciprocité," he postulated, "We have given the people and even our sages only one basis for morality, but it is extremely solid: reciprocity." ${ }^{83}$ Anticipating notions of fraternity that would soon sweep across the country, he equated reciprocity with the Golden Rule. "Unless one is crazy, one cannot reject this grand and beautiful truth: DO UNTO OTHERS AS YOU WISH THEY DO UNTO YOU." 84 Unlike barter, Rétif's reciprocity involved giving without necessarily receiving, or at least not immediately. The return might come indirectly, at a later time, or not at all. One's descendants might reap the benefits of one's generosity today, although to the degree one identified with one's progeny or the future of one's society, this could be considered recompense. 85 "Society" was central in all this because the balancing of accounts took place there, rather than through discreet exchanges between individuals. Still, just as Le Mercier had left space for generosity and obligation in his otherwise utilitarian schema, Rétif left room in his for rational self-interest. The chief benefits of reciprocity for the individual, he explained, were the avoidance of violence and the possibility of inspiring a return: "The entire science of morality can be reduced to behaving in such a manner that, not only will others not seek vengeance against us; they may also become fair through our example and even benevolent towards us, in consideration of our universal philanthropy." ${ }^{86}$

Reciprocity was thus morally elastic. It referred to self-interest and selflessnessto barter and generosity. This constructive ambiguity opened up all sorts of possible arguments. It helped the abbé Dorihac, during the financial crisis of 1788, turn a Gospel injunction to be generous into a justification for demanding interest on loans. The passage he cited (Luke 6:34) is hardly ambiguous: "Love your enemies . . . lend to them, expecting nothing in return." ${ }^{87}$ But Dorihac insisted that the passage referred to "the reciprocity of the loan" and not a free gift. ${ }^{88}$ His notion of reciprocity oscillated between generosity ("the sacrifice of my possession in your favor") and exchange equivalence: "there is a reciprocity of advantages [in the loan]; I am therefore not unjust in demanding revenues on the capital [i.e., interest] that I lend to you ...

83. Nicolas-Edme Rétif de la Bretonne, Les nuits de Paris, ou l'observateur nocturne, 8 tomes in 16 parts (London: n.p., 1789), 2:3:512.

84. Ibid., original capitals.

85. Ibid., 514.

86. Ibid., 524-25. The same argument was made in a dialogue on civic morality during the Revolution; see le Citoyen Bulard, Almanach d'Aristide ou Du vertueux républicain pour l'an III de la République (Paris: Chez Caillot, an III [1794-95]), 73: “A Citizen: I believe it in our interest to be benevolent. Aristide: In doing so with others, we have the right to expect an equivalent return. Our generosity is an act that provokes reciprocity."

87. Abbé Dorihac, Traité de la légitimité du prêt lucrative, ouvrage utile et instructif, pour les lä̈ques et pour les ecclésiastiques (London: 1788), 155-57.

88. Ibid., 155. 
they are the price of my service, which I am under no obligation to render." ${ }^{89}$ His reasoning may strike us as specious, but given reciprocity's ambiguous meanings, it may have convinced some readers. It certainly would have found sympathizers among the state's creditors, including the Church, which risked seeing the crown slash interest rates on existing loans. Indeed, the stakes of Dorihac's argument were hardly hypothetical. ${ }^{90}$

Though often conflated, barter and the Golden Rule were distinct propositions, more easily reconciled in the abstract than in practice. Giving unto others something equivalent to what they give unto you differs from giving unto others as you wish they would give unto you. In the first, equivalence is a precondition for the exchange; in the second, it is not—obligation takes its place. But in spanning both views, reciprocity accommodated liberal and social understandings of society. Much ink would be spilled in the modern era trying to clarify the matter. Was reciprocity (and its synonym, fraternity) about rational self-interest or civic selflessness? Did it refer to utilitarian barter or to the existential obligation to be kind to others?

Both conceptions of reciprocity had origins in Old Regime culture. Again, Karatani helps us to see how. He argues that the return of "reciprocity-in-higherdimension" - that idealistic mode of exchange-depends on the presence of the modes of exchange it seeks to transcend: redistribution and commodity exchange. ${ }^{91}$ I would add that the concept of reciprocity retained some of the morality of those two modes and oscillated between them. On the one hand, it expressed a secular, egalitarian reworking of Christian charity and noble generosity, principles deeply rooted in early modern redistributive culture. On the other, it referred to balanced utilitarian exchanges between moral equals-the essence of doux commerce. Enlightenment philosophers may have been persuasive in combining the two on the page, obscuring asymmetrical profit making in the process. But when the Old Regime collapsed, the moral tensions among all three exchange propositions-generosity, barter, and profit—would tear revolutionaries apart.

THE RISE AND FALL OF FREE-MARKET FRATERNITY

In retrospect, it seems odd that economic liberalism was ever justified in terms of reciprocity. Reciprocity implies balance; capitalism seeks profits. But it was precisely reciprocity's connotation of balance that made it an effective weapon against

89. Ibid., 53-54.

90. For the Church's loans to the regime, see Louis S. Greenbaum, Talleyrand: Statesman-Priest (Washington, DC: Catholic University of America Press, 1970), 38-39. I would like to thank William Doyle for this reference.

91. Karatani, Structure of World History, xii, 9-10, 307. 
caste and privilege. Projected onto commercial society, reciprocity offered a moral alternative to feudalism and mercantilism. The political economist and barrister from Orléans Guillaume-François Le Trône deployed the concept in this manner. A leading contributor to physiocratic publications in the 1760s and 1770s, Le Trône championed the cause of free trade, even of grain (a sensitive commodity), in the name of reciprocity. As early as 1764, he assured readers that "the reciprocity of Commerce will gradually unite us with other Peoples." ${ }^{92}$ If France sold its grain to other countries in their time of need, then "by the immutable Laws of humanity," they would reciprocate when hard times fell upon France. Free trade would lead to mutual assistance and happiness.

In making reciprocity the measure of social relations, Le Trône was able to expose the inherent injustices of feudalism. In a tract of 1779, expanded and republished posthumously in 1788 and cited by several authors in 1789, he urged readers to assess feudalism in the light of reciprocity. "To get a clear understanding of feudalism, the right point of view is perhaps to see it from the perspective of reciprocity, which shows [feudal] property to be fictive, leaving nothing that is real except fees, pains, and embarrassments." ${ }^{93}$ Feudalism involved multiple claims on property that enriched those at the top at the expense of those at the bottom. Everyone in between, at best, broke even, passing revenues extracted from below upward. More often they incurred losses through administrative and legal fees. The chief beneficiaries of this vexatious system were the dues collectors, feudal consultants, notaries, and lawyers. Ultimately, "feudal property is not only null in terms of reciprocity; it is onerous, very onerous." ${ }^{94}$

Even in exposing feudalism's inherent asymmetries, liberal economic notions of reciprocity obscured those inherent in commercial capitalism. In part, this obfuscation may have reflected the priorities of the age. In his study of eighteenth-century accounting practices, Pierre Gervais shows that merchants were less concerned about calculating profits and losses than they were about tracking credit flows. ${ }^{95}$

92. Guillaume-François Le Trosne [Trône], Discours sur l'état actuel de la magistrature, et sur les causes de sa décadence: Prononcé à l'ouverture des audiences du bailliage d'Orléans, le 15 novembre 1763, par M. Le Trosne, avocat du Roi (Paris: Chez Panckoucke, 1764), 76.

93. Le Trône, De l'administration provinciale, 2:476. Le Trône was cited as an authority in at least two tracts in 1789: Jacques-Antoine Boudin, Nouvelles réflexions sur le rachat des droits féodaux (Paris: Chez Desenne, 1789), 19; and Anonymous, De la Féodalité et de l'A ristocratie française: ou Tableau des effets désastreux des Droits féodaux; et Réfustation des erreurs sur lesquelles la Noblesse fonde ses prétentions (n.p., 1789), 18.

94. Le Trône, De l'administration provinciale, 2:477.

95. Pierre Gervais, “Why Profit and Loss Didn't Matter: The Historicized Rationality of Early Modern Accounting," Merchants and Profit in the Age of Commerce, 1680-1830, ed. Pierre Gervais, Yannick Lemarchand, and Dominique Margairaz (Cambridge: Pickering \& Chatto, 2014), 33-52. 
But profit making was also obscured by a tendency to present commercial exchanges as necessarily win-win relationships. Merchants might enrich themselves in the process, but society and "the nation" were the ultimate beneficiaries. "All are rich through the reciprocity of needs and the reciprocal utilities of exchange," declared Forbonnais in his full-throated praise of commerce. ${ }^{96}$ Although Adam Smith did not invoke "reciprocity" in The Wealth of Nations (the English term was just beginning to percolate in the 1770s, see fig. A6), the book's full title also implied that trade's benefits were collective. The study was, after all, "an inquiry into the nature and causes of the wealth of nations," not of merchants. Smith, in fact, held a dim view of merchants. ${ }^{97}$ Left to their own devices, they sought protections and subsidies and formed monopolies and combinations. These ills could be prevented only by the state, which, in establishing a competitive framework for commerce, would ensure that commercial gains would be enjoyed collectively.

The heyday of liberal economic conceptions of reciprocity came in the 1780s. Optimism about the reciprocal benefits of free trade, already expressed by the physiocrats in the 1760s and 1770s, pervaded the Peace of Paris meetings of 1783. ${ }^{98}$ The Correspondance secrète, which conveyed the opinions and gossip circulating in Parisian high society, summed up the reigning view about the commercial negotiations: "Freedom of trade and navigation across all seas will destroy a great many pretentions that might disrupt peace in Europe, since any [pretentions] that do not give rise to reciprocity will no longer exist. . . Balance will be established by bringing advantages to all peoples without any detriments; all will benefit." ${ }^{99}$ After some foot dragging and false starts, Britain and France finally concluded a liberal trade deal in 1786. Its adverse impact was immediately felt by France's fledgling manufacturing sector, which was nearly wiped out by a tsunami of cheap British goods. Defending the treaty from widespread criticism, one French writer insisted that its core principle of reciprocity ensured that mutual benefits would prevail in the long run: “This treaty will endure forever and, THANKS TO THE NATURE OF THINGS,

96. Forbonnais, Principes et observations ceconomiques (1767), 1:9. For a concise overview of this eighteenthcentury view of commerce, see Olivier Grenouilleau, Et le marché devint roi (Paris: Flammarion, 2013), chap. 5.

97. Nathan Rosenberg, "Adam Smith on Profits-Paradox Lost and Regained," Journal of Economic History 82, no. 6 (1974): 1177-90.

98. Le Trône, De l'administration provinciale, 1:56 n. 1. Le Trône saw free trade as "based on the reciprocity that justice prescribes to men and societies."

99. Entry for April 12, 1783, in Correspondance secrète, politique $\theta$ littéraire, ou mémoires pour servir à l'histoire des cours, des sociétés $\theta$ de la littérature en France, depuis la mort de Louis XV, 18 vols. (London: Chez John Adamson, 1787-1790), vol. 14. 
will be greatly beneficial to both nations . . . since it is based on the infallible principle-a reciprocity of advantages." ${ }^{100}$

Despite the hype, doubts about free trade's reciprocal benefits grew. Some saw reciprocity not as the natural effect of free trade but as a means of tempering free trade's imbalances. The shift was subtle at first but would accelerate after 1789. In confidential comments written on the British draft of a commercial treaty in 1786, Charles-Alexandre de Calonne, controller general of finances and outspoken supporter of free trade, conceded, "Liberty is without doubt the spirit of commerce, and we are disposed to extend it as far as possible. . . But," he added, "this freedom is merely an abstraction without reciprocity: it is essentially this reciprocity that we must establish." ${ }^{101}$ Achieving reciprocity, in other words, necessitated industry-byindustry bargaining, not total abandon to free-market forces. Some on the British side, sharing these doubts, rejected the free-trade and reciprocity rhetoric altogether. In a letter to the British negotiator in Paris (William Eden), the Earl of Sheffield wrote, "When men talk of liberality and reciprocity in commercial matters, it is clear either that they have no argument or no knowledge of the subject . . . it is not friendship or favour, but exactness and punctuality, that is looked for in commerce."102

Because of the outbreak of a court scandal (the Diamond Necklace Affair), the French crown, compromised and desperate for an achievement, caved to British demands for liberal trade. Its achievement looked like a failure once it became clear that the treaty favored Britain. Despite complaints and dissatisfaction, France upheld the treaty, more for geopolitical than economic reasons, until war broke out with Britain in 1793. ${ }^{103}$ Over the course of the agreement, misgivings about liberalized trade set in. Perhaps market freedom would not ensure reciprocity's promise of peace, balance, and mutual prosperity after all. For Pierre-Louis Goudard, a national deputy in 1790 and architect of far-reaching domestic economic reforms a year later, it was naïve to believe that reciprocity could be attained through free trade. The advantages and disadvantages of free trade were never evenly distributed, and countries would never honor such agreements if doing so undermined

100. Charles, le marquis de Casaux, Quatrième suite des considérations sur quelques parties du méchanisme des sociétés (London: T. Spilsbury. Se trouve chez P. Elmsley, 1788), vii. For France's trade deficit with Britain between 1784 and 1788, see John Ehrman, The British Government and Commercial Negotiations with Europe, 1783-1793 (Cambridge: Cambridge University Press, 1962), 194n, 220-21.

101. “Observations à communiquer confidentiellement à M. Eden sur son projet de Traité," Auckland Papers, British Library, carton 34421, fol. 101.

102. John Holroyd, Earl of Sheffield, Observations on the Commerce of the American States (London: Debrett, 1783), 111.

103. For balance-of-trade statistics showing Britain's advantage at France's expense and for France's geopolitical motivations for maintaining the agreement, see Walton, "Fall from Eden," 52, 55. 
their interests. ${ }^{104}$ The historian and elected member of the Academy of Moral and Political Sciences during the Directory, Louis-Pierre Anquetil, expressed similar skepticism five years later. He concluded his history of Bourbon wars with a critique of the Anglo-French commercial treaty of 1786, advising that France avoid making such treaties in the future. By doing so, "we will no longer expose ourselves to being surprised by the unbalanced [trade] conditions that are presented under the guise of an equitable reciprocity." ${ }^{105}$ At least one political economist of the late 1790s doubted whether equity and mutual benefits had any relation to commerce at all. Antoine Français de Nantes, a former Jacobin and now democraticrepublican deputy in the Council of Five Hundred, saw commerce as inherently unreciprocal: "However democratic one may be, one must admit that, while equality is essential for representative government, inequality is both the cause and consequence of commerce." ${ }^{106}$

Reciprocity's gradual disappearance from justifications for commercial freedom during the Revolution is perceptible in debates over the domestic economy as well. In 1789, optimism about reciprocity and commercial freedom was still in the air, and it penetrated the National Assembly. It crystallized in a decree on August 29, liberalizing the grain trade. The text of the decree was drenched in notions of fraternal sentimentality. It called upon "all Frenchmen to regard each other as true brothers, always disposed to give each other all kinds of reciprocal assistance."107 But "reciprocal assistance" referred to the free market. Anyone suspected of intervening in it-be they individuals, crowds, or officials—was to be charged with the high crime of lèse-nation, a kind of sedition.

104. Pierre-Louis Goudard, Rapport fait à l'Assemblée nationale, au nom du Comité du commerce et d'agriculture, sur la suppression des droits de traite perçus dans l'intérieur du royaume, le reculement des douanes aux frontières, et l'établissement d'un tarif uniforme (Paris: Imprimerie nationale, 1790), 20.

105. Louis-Pierre Anquetil, Motifs des guerres et des traités de paix de la France pendant règnes de Louis XIV, Louis XV et Louis XVI, depuis la paix de Westphalie, en 1648, jusqu'à celle de Versailles, en 1783 (Paris: Lesguilliez frères, 1797), 380. Others also questioned the treaty's "reciprocal" benefits: “The experience of [the treaty] has convinced us, to our detriment, that the apparent reciprocity of the commercial treaty of Versailles is entirely null for France and favors, in the final analysis, only England." Jules Gautier, Essai sur la restauration des finances de la France et sur l'organisation générale et administrative de l'agriculture et du commerce... (Marseille: Imprimerie de Bertrand, 1799), 161.

106. Antoine Français de Nantes, Coup-d'ail rapide sur les mœurs, les lois, les contributions, les secours publics, les sociétés politiques, les cultes, les théâtres, les institutions publiques, dans leurs rapports avec le gouvernement représentatif et sur tous les moyens propres à affermir la constitution de l'an III (Grenoble: P. Cadou et David aîné, 1795-96 [year 4]), 7. I would like to thank Minchul Kim for sharing his work on Français de Nantes with me.

107. Jérôme Mavidal and Émile Laurent, eds., Archives parlementaires de 1787 à 1860: Recueil complet des débats législatifs et politiques des Chambres françaises, 82 vols. (Paris: P. Dupont, 1867), 8:510-11. 
The National Assembly's early free-market policies divided revolutionaries. Some remained committed to the belief in their mutual, long-term benefits. Speaking on behalf of the wholesale merchant community, Joseph-Jean-Chistostôme Farcot insisted in 1791 that free markets would bring about not only national prosperity but also world peace. Countries adopting free trade, he reasoned, would inspire others to imitate them. Through "a reciprocity of benefits," free trade would bring about "a reciprocity of liberty" and "a general peace among all the peoples of the world." ${ }^{108}$ But others were less sanguine, especially those worried about subsistence. In 1791, the General Council of the Paris Commune expressed its concerns about "the [current] laws that protect the free circulation of [grain] in the kingdom ... It is uncertain that commerce alone . . can ensure the provisioning of Paris." 109

Even some advocates of commercial freedom began acknowledging that free markets might not protect foodstuffs from speculation and that a different kind of reciprocity - that of obligation rather than market forces-might be needed. In late 1792, as France slid deeper into chaos and grain became scarce, a deputy from Marseilles, Charles Jean Marie Barbaroux, called for a middle course between absolute property rights and market freedom on the one hand and price ceilings and requisitioning on the other. He proposed allowing merchants to oblige fellow merchants to sell them half their grain at cost. In distributing grain supplies more widely, the policy would discourage hoarding and lower prices. It would not violate property because it was based on "a reciprocity of rights: . . what a merchant gives one day might be returned the next."110 This was reciprocity in its generous, Golden Rule rather than liberal economic mode. Antoine François Bertrand de Molleville, minister of the Navy and of the Colonies between 1790 and 1792, espoused a similar notion of reciprocity-one that placed it in its generosity-obligation rather freemarket register. To rescue the economically devastated colony of Saint Domingue in 1791, he urged metropolitan merchants, who had profited so much from the slave colony in the past, to freely give-and not just lend-to the colony in its hour of need. "This reciprocity of exchanges and wealth, so advantageous for France,

108. Joseph-Jean-Chisostôme Farcot, Questions constitutionnelles sur le commerce et l'industrie et projet d'un impôt direct sur les commerçans et gens à l'industrie ... proposés à l'Assemblée nationale par des négociants français (Paris: Chez Le Clère, 1790), 131-32.

109. Extrait des registres des délibérations du conseil générale de la Commune de Paris in Jacques Peuchet, Jurisprudence: contenant la police et les municipalités, 10 vols. (Paris: Panckoucke, 1791), 10:791.

110. Opinion de Charles Barbaroux, de Marseille, député par le département des Bouches-du-Rhône, à la Convention nationale, sur les causes de la cherté des grains et les moyens d'y remédier (Paris: Imprimerie nationale, 179-), $18-19$. 
obliges us in this moment to repair the damage suffered by these rich establishments." 111

The free-market policies of the early Revolution gave way to price controls and requisitioning during the Terror (1793-94). As France became embroiled in civil and foreign wars, reciprocity and its synonym, fraternity, remained squarely in the generosity and obligation register. Pieties about the reciprocal benefits of self-interest and free markets were not aired, at least not openly. When economic liberalism was revived during the Directory, reciprocity scarcely figured in justifications for it. The term appeared mostly in discussions of matters other than commerce, such as state-society relations, social contracts, and the need for mutual esteem among citizens. The few tracts that did link reciprocity to commercial freedom were reeditions of earlier works. The 1796 edition of Forbonnais's midcentury Élements $d u$ commerce (larded, as we have seen, with more instances of "réciprocité" than the original) was an exception. In general, the concept became detached from liberal economic theory. Along with its synonym fraternité, réciprocité frowned on economic egoism - a disposition expressed in full force during the Terror. (It appeared in an inscription mounted on a guillotine in the town of Moulin: "Aristocrats, the rich, egoists, and starvers of the people, tremble!"112 ) This social, as opposed to liberal, disposition clung to the term into the nineteenth century. It shows through in the entry for "réciprocité" in Dictionnaire universel de la langue française of 1835: "The social order is a vast system of exchanges, sacrifices and reciprocities. The egoist who gives nothing has the right to nothing. He disturbs the social order. He destroys it." ${ }^{113}$

The Terror phase of the Revolution thus appears to have brought an end to the early Revolution's free-market fraternity rhetoric, itself a product of Enlightenment theories of commercial society. Fraternity acquired reciprocity's Golden Rule associations, as a dictionary of neologisms in 1795 made clear: "Fraternity is the cradle of civil society . . . it commands men to do unto others what you would wish to have done unto you."114

111. Antoine-François, marquis de Bertrand de Molleville, Mémoires secrets pour servir à l'histoire de la dernière année du règne de Louis XVI, 3 vols. (London: Strahan \& Cadell, 1797), 1:311.

112. Pierre Caron, ed., Rapports des Agents du Ministre de l'Intérieur dans les Départements (1793-an 2), 2 vols. (Paris: Imprimerie nationale, 1913), 1:465.

113. Pierre Claude Victoire Boiste and Charles Nodier, Dictionnaire universel de la langue française, avec le latin et les étymologies . . . , 8th ed. (Brussels: Méline, 1835).

114. Léonard Snetlage, Nouveau dictionnaire français contenant les expressions de nouvelle création du peuple français: ouvrage additionel au dictionnaire de l'Académie française et à tout autre vocabulaire (Göttingen: J. C. Dieterich, 1795), 98-99; emphasis in original. 


\section{BECOMING CAPITALISM'S ANTITHESIS AND ALTER EGO}

As invocations of reciprocity skyrocketed in the nineteenth century (see figs. A4 and A5), the concept came to be seen as the antithesis of free-market capitalism. This view is discernible in three domains: international trade, political philosophy, and the social sciences.

In international relations in the nineteenth century, free trade and reciprocity were no longer seen as mutually reinforcing principles. They were stark alternatives. "Hurrah for Free Trade; down with Reciprocity!" wrote an author in 1870, voicing his liberal sympathies on the matter. ${ }^{115}$ A decade later, Samuel Smith offered a lengthy discussion of this debate in his seminal and much cited Free Trade versus Reciprocity. ${ }^{116}$ Even those who believed free trade and reciprocity were one and the same acknowledged that they were challenging conventional views. ${ }^{117}$ The debate stretched back at least to the 1840s, when reciprocity became the battle cry of the fair-trade movement, which opposed the liberal doctrines coming from Britain. ${ }^{118}$ "Without reciprocity," the Germans insisted in their negotiations with Britain, "free-trade does absolute harm to the state which 'generously' sacrifices everything to its principles." ${ }^{119}$ As Calonne had realized in his dealings with Britain in the 1780s, reciprocity would require active bargaining to achieve a balance of benefits, not passive submission to market forces. For their part, the advocates of free trade dismissed their fair-trade opponents as "reciprocity-mongers," a term that gained enough currency to merit an entry in the Oxford English Dictionary. ${ }^{120}$

115. Commercial Treaties: Free Trade and Internationalism. Four Letters (London: Macmillan, 1870), 25. 116. Samuel Smith, Free Trade versus Reciprocity (1881; Miami: HardPress, 2014).

117. The anonymous author of Reciprocity, by a Manufacturer (Leeds: Baines \& Newsome, 1844) refuted the common distinction made between free trade and reciprocity, arguing, "In trade, a man cannot benefit himself without to a certain extent benefiting others ... all classes aid, willingly or unwillingly, in supplying the wants of the people.... Here is manifest the true spirit of reciprocity, which constitutes a portion of our nature, and, like the physical growth of the human frame, requires only full scope [i.e., free trade] to develop itself" (46). Another writer (a "Disciple of Richard Cobden") concluded, "Instead of finding the idea of reciprocity arrayed in opposition to the idea of free trade, we find the two to be inseparable companions." Commercial Treaties, 27.

118. For recent historical treatments of these debates in Britain, see Douglas A. Irwin, "The Reciprocity Debate in Parliament, 1842-1846," in Free Trade and Its Reception, 1815-1960, ed. Andrew Marrison (London: Routledge, 1998), 129-46; Peter T. Marsh, Bargaining on Europe: Britain and the First Common Market, 1860-1892 (New Haven, CT: Yale University Press, 1999), 110. With its vast empire and superior trade volume, Britain stood to benefit from free trade.

119. Cited in Marsh, Bargaining on Europe, 110.

120. The OED Online (Oxford: Oxford University Press, 2016; www.oed.com.pugwash.lib.warwick.ac .uk/view/Entry/159546?redirectedFrom=reciprocity), dates "reciprocity-monger" to the latter half of the nineteenth century. In his book about democracy, the British historian and free-trade supporter Arthur Crump insisted that "reciprocity-mongers" would never "fail to disturb the convictions of the sound thinkers, whose faith in Free Trade principles cannot be shaken"; A Short Inquiry into the Formation of Political Opinions from the Reign of the Great Families to the Advent of Democracy (London: Longmans, Green, 1885), 198. 
While diplomats and economists wrangled over the terms of international trade, philosophers and social scientists developed reciprocity into an ethical norm and heuristic concept. Here, too, it stood opposed to free-market capitalism. In that lengthy definition of reciprocity in Dictionnaire universel du XIXe siècle (discussed earlier), Larousse observed that the principle informed many of the social contract theories of the day. Based on those theories, he predicted that reciprocity would bring an end to capitalism: "With every day [reciprocity] tends to replace antagonisms, which, until now, have been considered necessary to social organization, producing distinctions, class hierarchies, and competition among individuals." ${ }^{121}$ Unlike capitalism, reciprocity necessitated equality: “As long as men are not considered equal ... reciprocity can be neither imagined nor practiced, since its fundamental principle is equality of rights, functions, responsibilities, and relations." ${ }^{122}$ For all his misgivings about capitalism, Larousse did not consider communism and socialism viable alternatives. Communist states were too unwieldy to manage supply and demand efficiently; socialism was too utopian in believing that competition could be suppressed.

Despite his rejection of socialism, Larousse echoed the views of the socialistanarchist Pierre-Joseph Proudhon, including Proudhon's critique of the common conflation of fraternity and reciprocity. In his Idée générale de la Révolution au XIXe siècle, published on the eve of Louis-Napoleon Bonaparte's overthrow of the Second Republic in 1851, Proudhon wrote that, although he admired the "fraternal sentiments" of the Parisian worker associations, which were establishing barter networks, he did not think that such sentiments were sufficient for establishing a new social order. (Incidentally, one of the worker associations he discussed was named La Réciprocité.) Proudhon distinguished between "charitable sentiments" and reciprocity. The latter, he explained, "consists in sellers and buyers guaranteeing each other, irrevocably, their products at cost price." ${ }^{123}$ Adopting a materialist view, he believed that reciprocity was ultimately achieved through exchange practices based on contract; fraternal sentiments were the result, not the source, of those practices. ${ }^{124}$

It is ironic that Proudhon's socialist thinking had much in common with that of economic liberals of the Enlightenment. Like them, he described reciprocity in terms of barter and, on that basis, sought to legitimize a new social order. Like them,

121. Larousse, Dictionnaire universel du XIXe siècle, 13:779.

122. Ibid.

123. Pierre-Joseph Proudhon, General Idea of the Revolution in the Nineteenth Century, trans. John Beverly Robinson (1851; Mineola, NY: Dover, 2003), 91.

124. Ibid., 90: "What would become of them [worker associations] if they did not find the guarantee of their enterprise elsewhere than in the charity [i.e., fraternity] which animates them and which is but the cement of the edifice, whereof the stones are labor and the forces which multiply labor?" 
he combined the reciprocity of goods and services with the reciprocity of rights and duties-a "conflation" of economic and political principles for which the economist Léon Walras would later criticize him. ${ }^{125}$ And like the physiocrats, Proudhon understood reciprocity to consist of balanced exchanges that, over time, strengthened social and sentimental bonds.

So perhaps Alexis de Tocqueville was right when he observed in The Old Regime and the French Revolution (1856): "It is commonly thought that the subversive theories of what today is known as socialism are of recent origin. This is not so; views of this kind were sponsored by the earliest Economists [the physiocrats]." ${ }^{126}$ Of course, there were a great many differences as well. Whereas the physiocrats had invoked reciprocity to discredit privileges and monopolies, Proudhon invoked it to discredit profit and private property. And whereas the physiocrats had obscured the wealth inequalities produced by capitalism, Proudhon saw such inequalities as capitalism's very essence.

In the early twentieth century, reciprocity entered anthropology. So, too, did its conceptual tensions between self-interest and generosity and between barter and the Golden Rule. Bronislaw Malinowski spent years meticulously classifying the exchange practices of archaic societies according to the motives of interestedness and disinterestedness-an undertaking that Marcel Mauss found deeply misguided. ${ }^{127}$ In his seminal The Gift: Forms and Functions of Exchange in Archaic Societies (1925), Mauss argued that these conceptual oppositions-self-interest versus selflessness, Homo economicus versus altruism-were recent inventions, the products of modern law and economics. ${ }^{128}$ He deconstructed them by showing how they were intertwined in archaic societies. What moderns took to be stark alternatives were, in the "melting pot" of archaic societies, all "jumbled up together." In this jumble, Mauss thought to have "discovered one of the bases of [all] social life." Even in capitalist societies, he believed, generosity and obligation (i.e., the gift) persisted, "hidden, below the surface." ${ }^{129}$ By revealing how utilitarian self-interest and the gift op-

125. Léon Walras, L'économie politique et la justice: Examen critique et réfutation des doctrines économiques de M. J.-P. Proudhon, précédés d'une introduction à l'étude de la question sociale (Paris: Librairie de Guillaumin et Cie., 1860), 63-65.

126. Alexis de Tocqueville, The Old Régime and the French Revolution, trans. Stuart Gilbert (New York: First Anchor, 1955), 163. It is worth noting, however, that de Tocqueville erred in presenting the obscure Enlightenment philosopher Étienne-Gabriel Morelly as a physiocrat. Morelly opposed many of the fundamental principles of the Gournay Circle and physiocrats; see the editor's introduction to Étienne-Gabriel Morelly, Code de la nature: Édition critique, ed. Stéphanie Roza (n.p.: Éditions qui brûle, 2011).

127. Mauss, The Gift, 93.

128. Ibid., 91-100. For a penetrating discussion of this aspect of The Gift, see Jonathan Parry, "The Gift, the Indian Gift and the 'Indian Gift,'" Man, n.s., 21, no. 3 (September 1986): 453-73, esp. 457.

129. Mauss, The Gift, 5. 
erate together in modern society (he gave several examples at the end of the essay), he hoped to "throw a light on the path that our nations must follow, both in their morality and their economy." 130

Mauss's deconstruction of these dichotomies-self-interest and selflessness, freedom and obligation, barter and gift-amounted to a deconstruction of reciprocity itself. As I have argued, these dichotomies, or tensions, have been present in the philosophical concept since its birth in the eighteenth century. But Mauss's essay did not put them to rest. Social scientists and philosophers have continued grappling with them ever since. In his Stone Age Economics (1974), Marshall Sahlins proposed a classification scheme that distinguished between "balanced reciprocity" (even exchange) and "generalized reciprocity" (the Golden Rule, gift and obligation). ${ }^{131}$ In Le don des philosophes: Repenser la réciprocité (2012), the philosopher and anthropologist Marcel Hénaff showed how these tensions reverberate in the gift theories of Jacques Derrida, Emmanuel Levinas, and Paul Ricoeur. ${ }^{132}$ He aimed to resolve them by distinguishing market and ritual forms of reciprocity-a crucial distinction, he believes, that these philosophers overlooked. Ritual reciprocity, he explained, concerns honor and mutual recognition, not utilitarian exchanges. Yet, as we have seen, honor and mutual recognition were at stake in reciprocity's earliest uses in post-Westphalian commercial treaties, well before utility and trade balances were brought to bear on the term during the Enlightenment. Again, it appears that recent theories about reciprocity express ideas and tensions stretching back to the term's origins in the seventeenth and eighteenth centuries.

The aim of this study has been to uncover these origins. I have located them in ideas of moral equality and the social forces of capitalism. The concept of reciprocity, I have argued, carried the moral traces of early modern redistributive orders (Christian charity, noble generosity) and modern commerce (barter, contract). Above all, I have aimed to explain how the concept evolved from justifying economic liberalism to becoming its "antithesis and alter ego" (Weiner). The French Revolution marked a key turning point. Before 1789, reciprocity's egalitarian connotations were useful for economic liberals in their campaign against privilege, patronage, and protectionism. After the failure to stabilize a new regime based on liberal economic principles after 1789 , reciprocity's ties to economic liberalism were sundered. The inequalities produced by capitalism betrayed reciprocity's promise of equity, mutual prosperity, and solidarity. Although more research is needed to chart reciprocity's course across the nineteenth and twentieth centuries-occurrences of

130. Ibid., 100

131. Marshall Sahlins, Stone Age Economics (Chicago: Aldine-Atherton, 1972).

132. Marcel Hénaff, Le don des philosophes: Repenser la réciprocité (Paris: Le Seuil, 2012). 
the term run in the tens of thousands rather than the mere hundreds-dictionaries and prominent texts suggest that reciprocity became the watchword of socialists and social scientists seeking conceptual alternatives to free-market capitalism.

So perhaps the rise of reciprocity in the humanities and social sciences since the 1980s (fig. Al and A2) is yet another manifestation of a pattern stretching back more than two centuries. Perhaps it expresses a desire to imagine social bonds in terms other than those offered by Homo economicus. If so, it would appear that reciprocity continues to be bound up with capitalism, playing the role of its conceptual countermovement, its antithesis, its alter ego.

\section{APPENDIX}

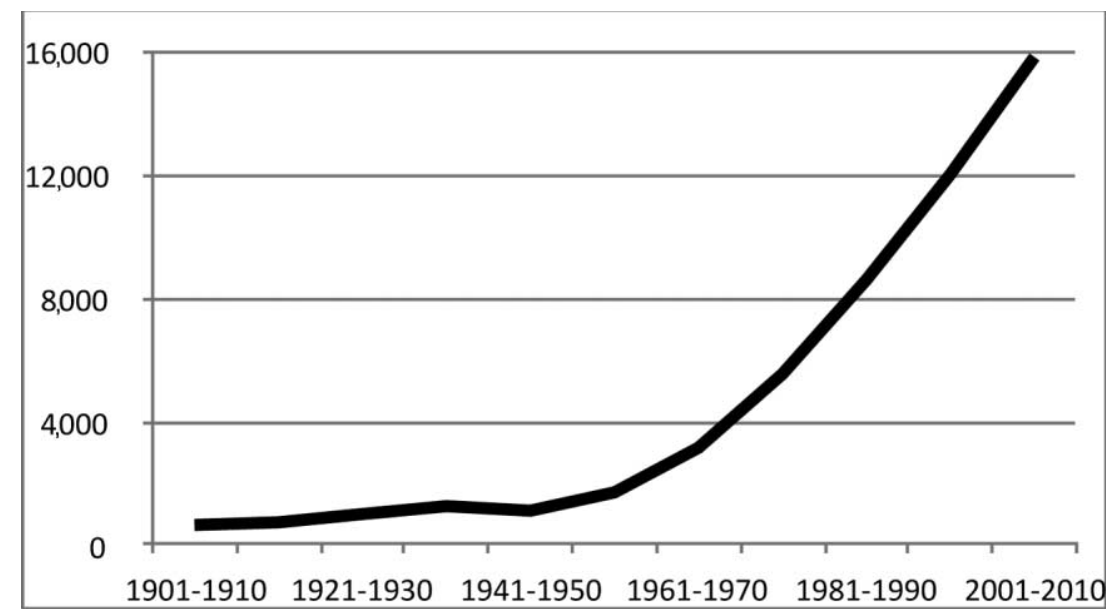

Figure A1. Articles in JSTOR in which "reciprocity" appears anywhere in the text between 1901 and 2010. 


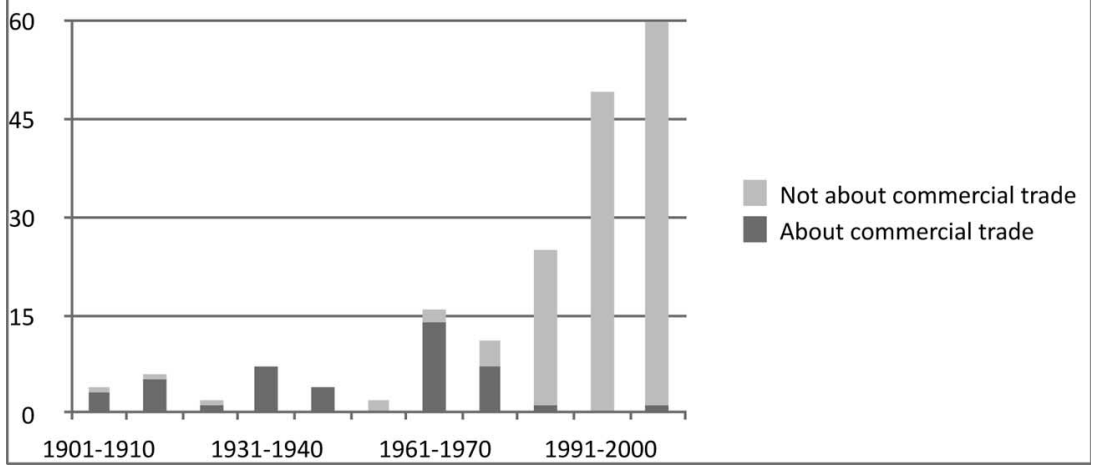

Figure A2. JSTOR titles (articles and other kinds of academic texts) with "reciprocity" in the domains of history, history of science and technology, and the humanities. The chart shows the relative proportion of texts using the term in the contexts of commercial trade and sociological or philosophical analysis. 


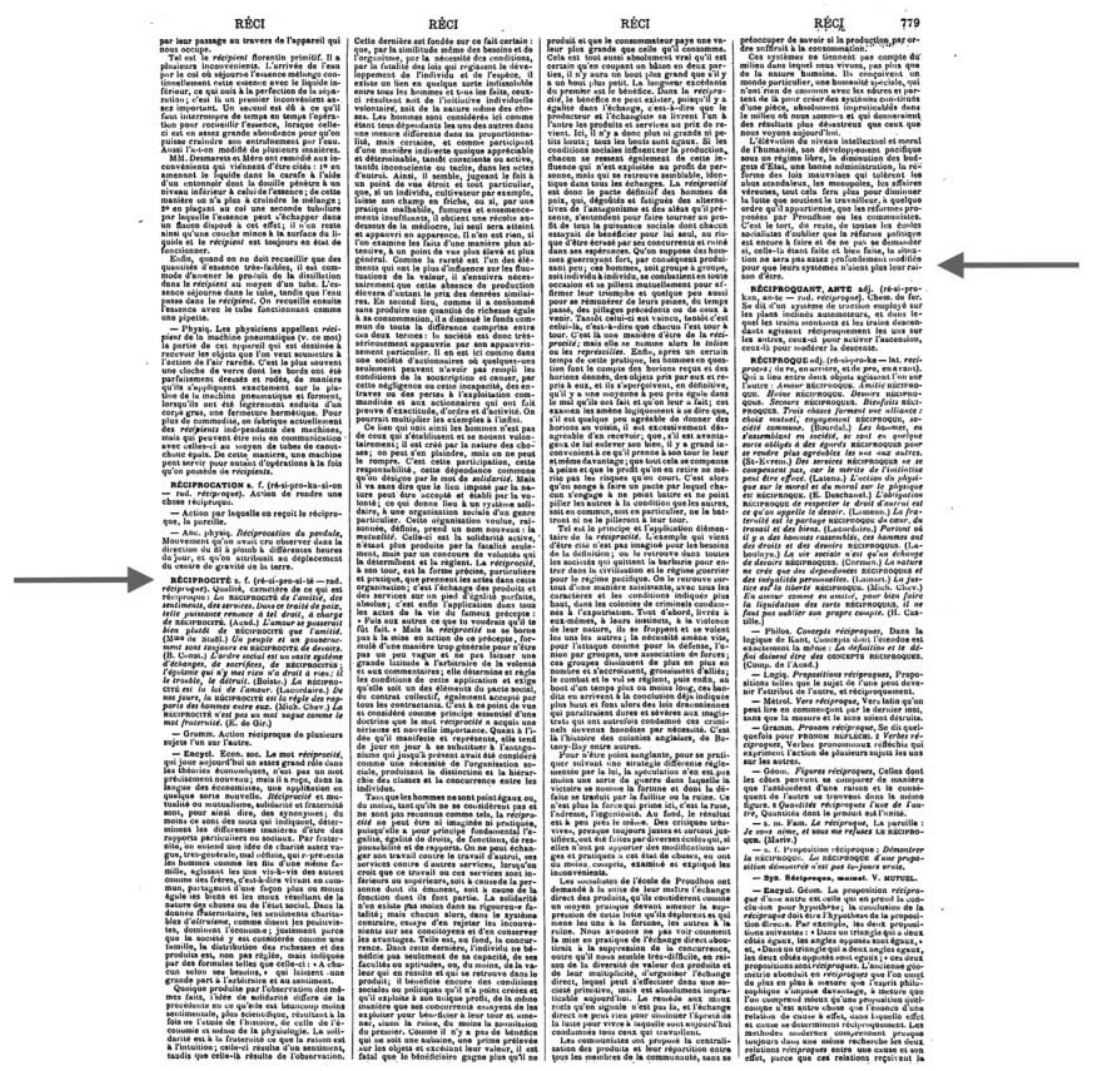

Figure A3. Definition of "réciprocité" in Pierre Larousse's Grand Dictionnaire universel du XIXe siècle (Paris: Administration du Grand dictionnaire universel, 1875), 13:779. 


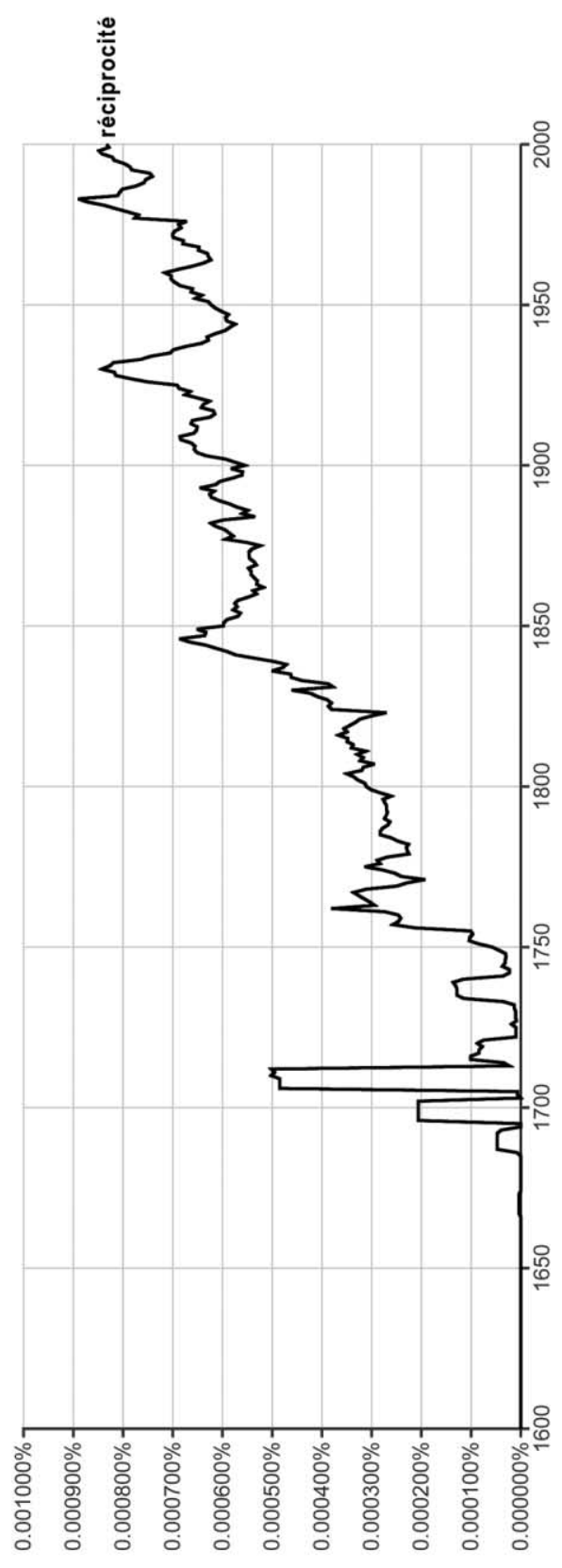

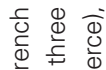

崖它

음

过

0 응

$\frac{1}{0} \frac{\sqrt[m]{x}}{x}$

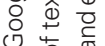

$\subseteq$ गे

들 है

谒

\% है 응

की क

这

市

흠 응

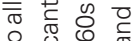

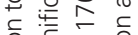

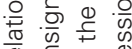

$\stackrel{2}{\triangleq}$

$=0$

둥

은 0

응

$=2.0$

过

送

ᄂ

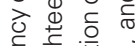

Ф․ㅡㅇ

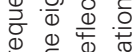

要考

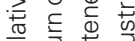

递

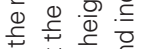

范范

की

क क

बis

궁

ह

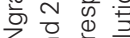

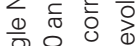

8 잉

은

过市章离

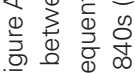

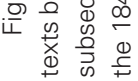




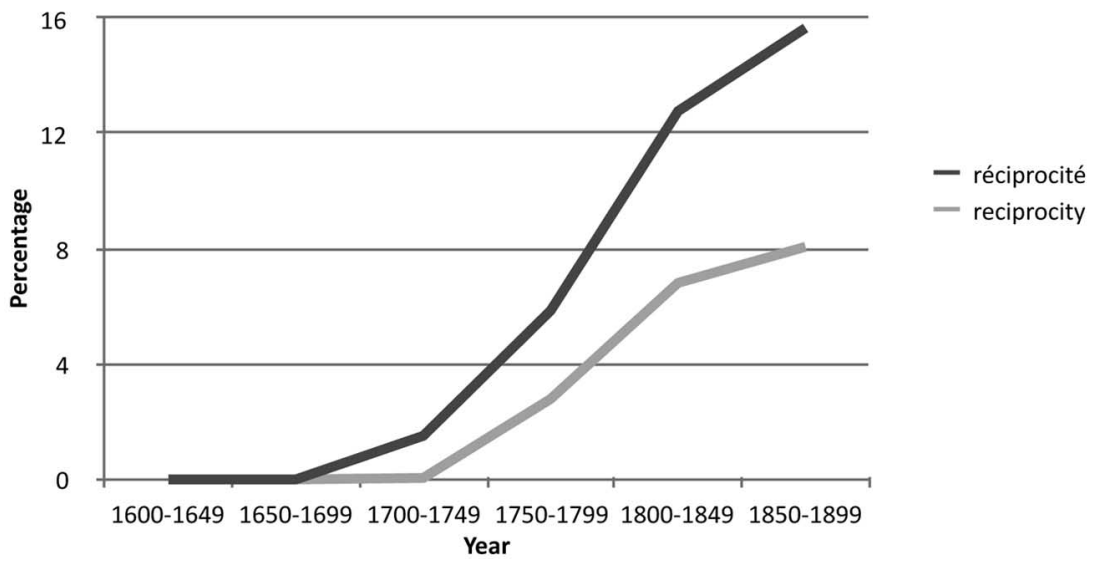

Figure A5. Comparative frequencies of the French "réciprocité" and the English "reciprocity" in "The Making of the Modern World" text collection. The percentages refer to the proportion of books in which the term appears at least once. 


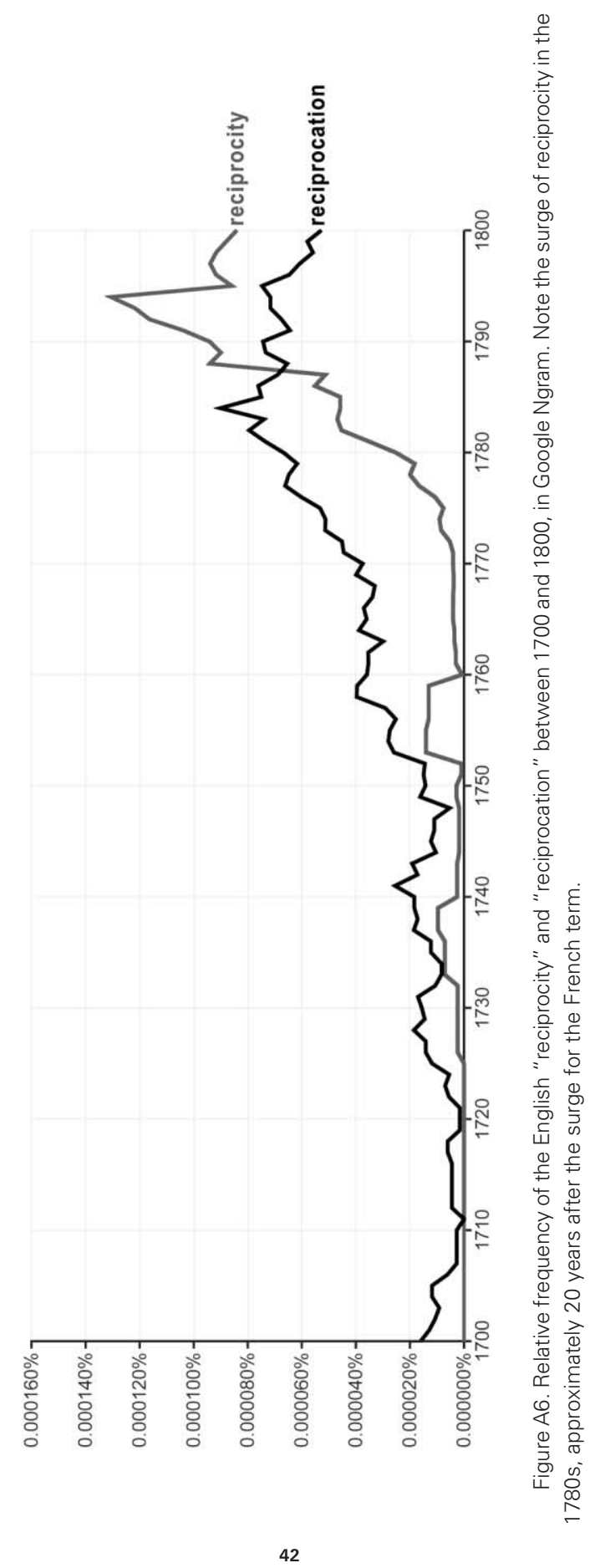




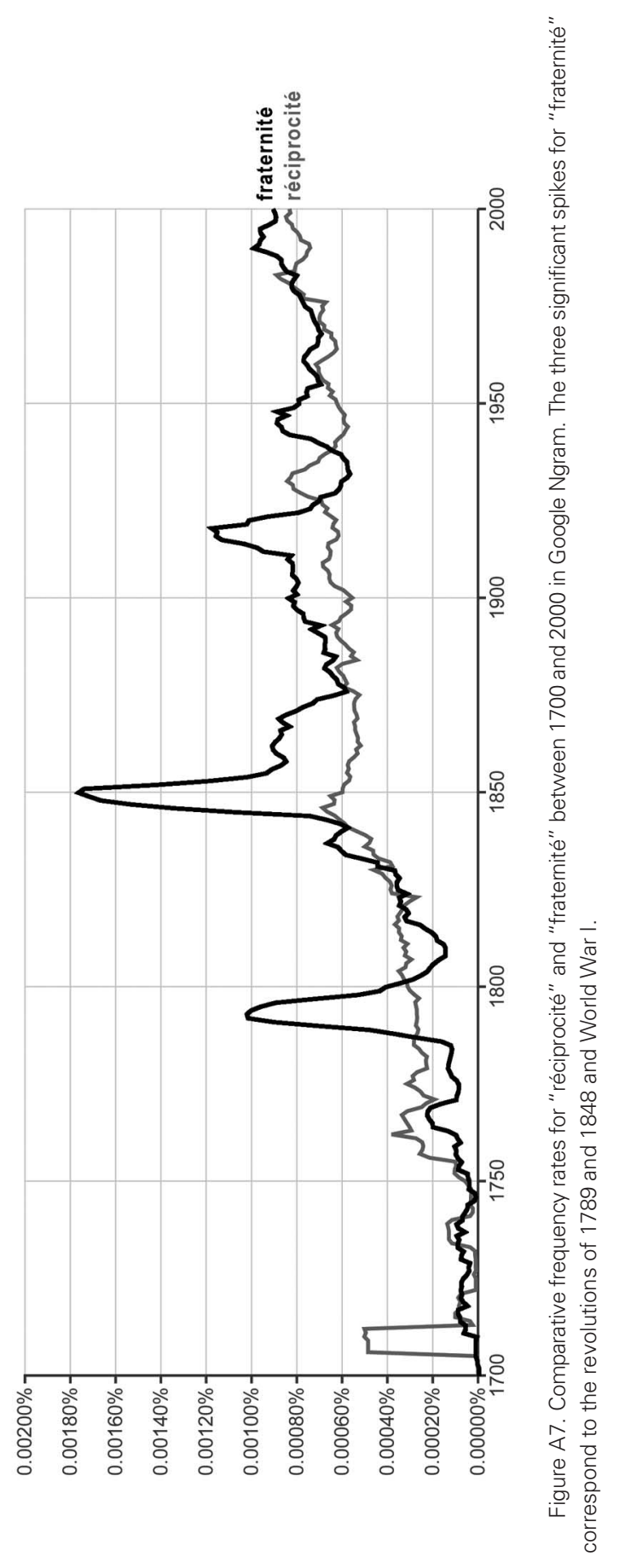

43 